\title{
$\mathrm{PH} \mathbf{8 9}$
}

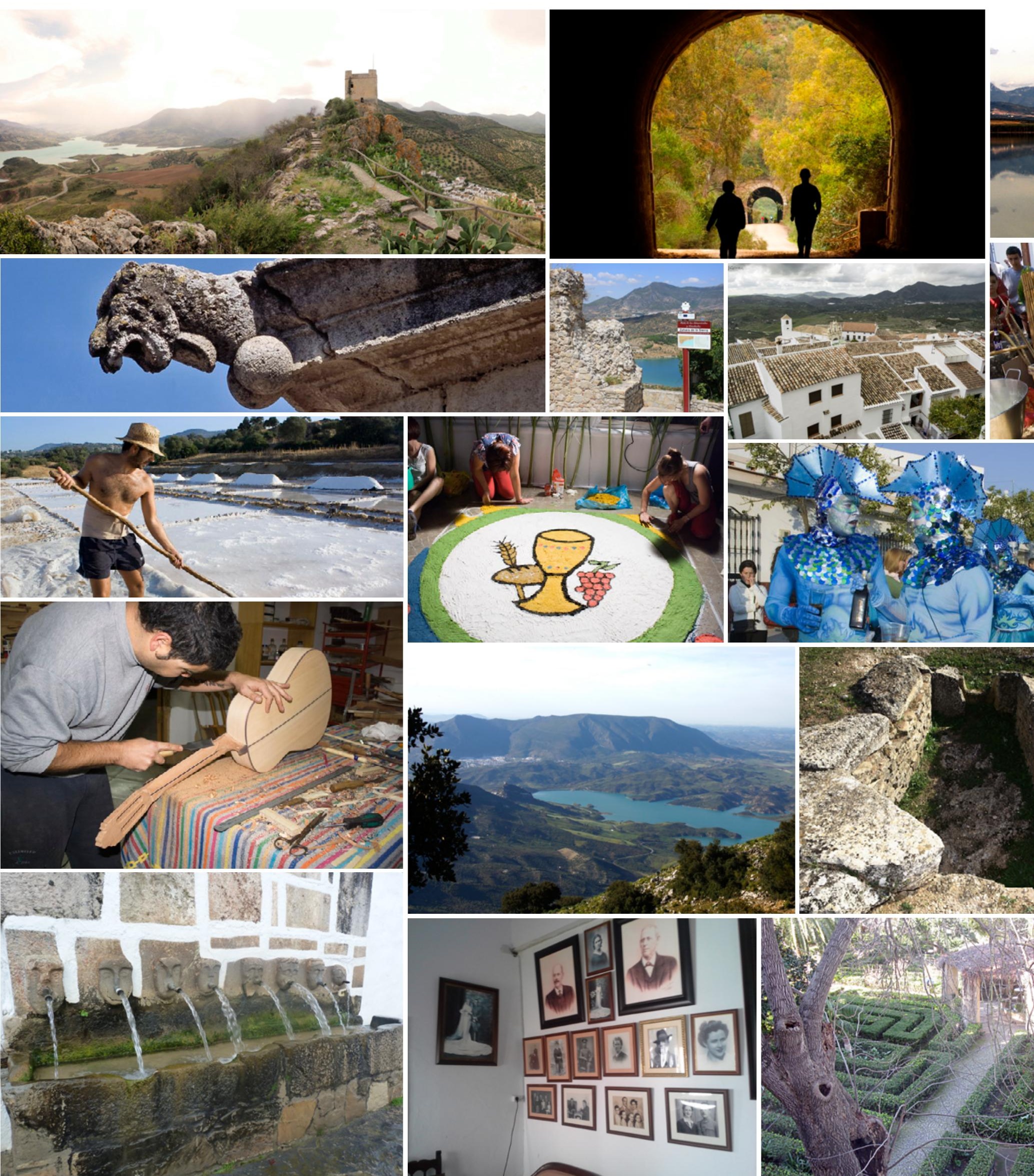




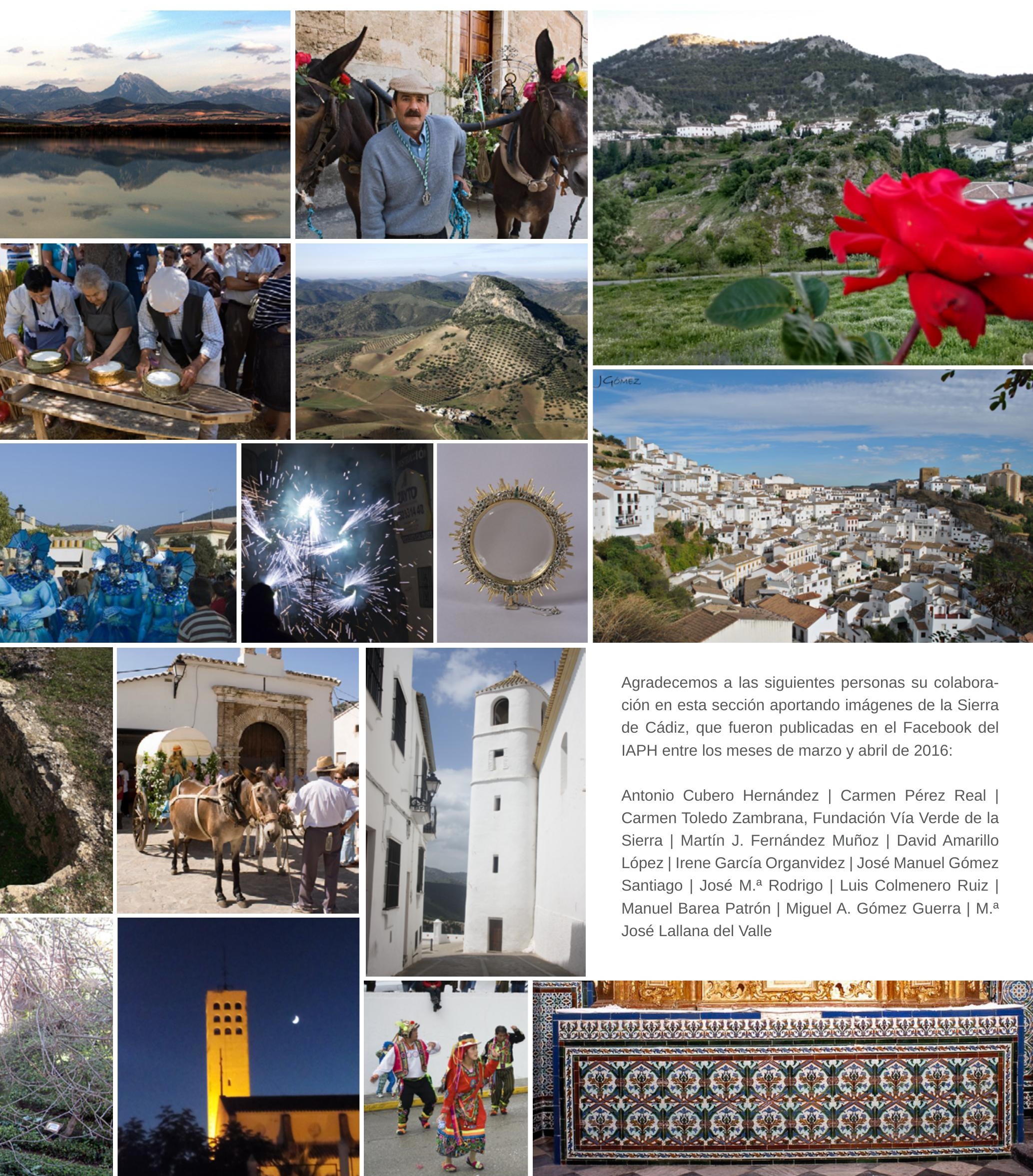


$\mathrm{PH} 89$

\section{La Sierra de Cádiz: paisaje y memoria}

Juan Manuel Suárez Japón | catedrático de Geografía Humana

URL de la contribución <www.iaph.es/revistaph/index.php/revistaph/article/view/3749>

\section{RESUMEN}

De una idea inicial de su tesis doctoral que versaría sobre El hombre y la montaña en la Sierra de Cádiz, y de sus primeros contactos con el que sería su objero de estudio, nace la fascinación del autor por este territorio.

En este texto conduce al lector al descubrimiento del paisaje cultural serrano, a través de preguntas y respuestas que, aunque enmarcadas en el trabajo preciso del investigador, construyen un discurso "personal" y cercano que permite tener una primera presentación completa y apropiada de la serranía gaditana.

Palabras clave

Cádiz (Provincia) | Memoria | Paisaje cultural | Sierra de Cádiz | 


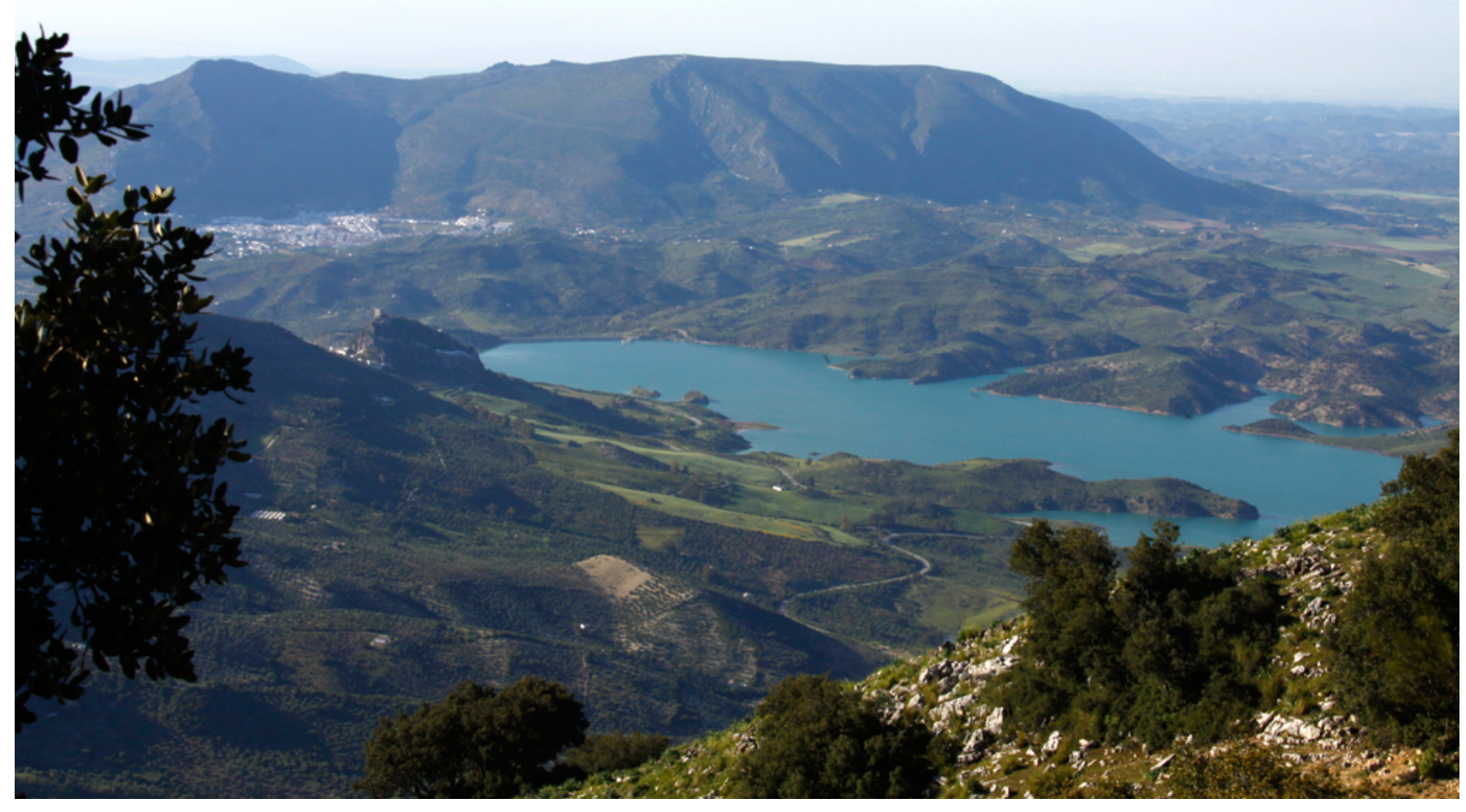

Gran murallón de la sierra de Líjar al fondo, con el pueblo blanco de Algodonales a sus pies. Más cerca, embalse de Zahara que recoge las aguas del Guadalete casi recién nacido. En el extremo del pantano, Zahara de la Sierra que muestra la torre del castillo y parte de su blanco caserío | foto José María Rodrigo Cámara 
Mi primera decisión fue clara: la tesis doctoral versaría sobre El hombre y la montaña en la Sierra de Cádiz. Haría un estudio a imagen y semejanza de la obra que Jules Blache había publicado en 1933 y que había puesto en mis manos el Dr. Rubio Recio, director de mi investigación. La idea se afianzó en cuanto me adentré por los caminos de aquella Cádiz interior -a la que la propaganda oficial catalogaba como la de los "pueblos blancos"-, en la que fui descubriendo un territorio habitado por la fascinación. Todo estaba allí dispuesto para conformar un universo que nos interrogaba: sus altos relieves, sus bosques, los apiñados núcleos agarrados a las pendientes, los caseríos salpicados como gritos blancos sobre las praderas o las lomas, los cauces orillados de altas choperas de color cambiante, las piedras añejas de las fortalezas, en suma, su paisaje. Pero entonces, jay!, todavía el paisaje era un concepto que se movía lejos de las preocupaciones protectoras y las realidades patrimoniales. Por fortuna, cuando esto fue de otro modo y el paisaje alcanzó su valor primero y primario, el tiempo y las mudanzas sobrevenidas sobre estas sierras gaditanas -pese a alguna mordida perniciosa-, habían respetado las grandes visiones que nos siguen hoy mostrando la maravillosa alianza que allí forjaron la naturaleza y la cultura. Así pues, antes de analizar las partes de esta realidad serrana, conviene detenerse en la comprensión del todo, es decir, de su paisaje como núcleo y marco, fuera del cual sus elementos patrimoniales quedarían huérfanos de sus razones últimas.

Cuando las voces de la Sierra de Cádiz comenzaron a interrogarme, busqué respuestas en quien entonces podía tenerlas, el arcense Jesús de las Cuevas, quien, junto a su hermano José, había escrito "las biografías" de aquellos pueblos, incluyendo en ellas un aparato crítico inmenso -inesperado en ese tipo de obras-, que me abrió las puertas. Fue un paso decisivo, porque estas lecturas me aportaron el saber de aquello que no podía verse, los sustantivos elementos intangibles que en todo paisaje habitan. Aprendí el origen de sus núcleos y la explicación de sus arriesgados emplazamientos y conocí las modestas épicas de sus fortalezas, la evocación de un tiempo en que aquel territorio fue la frontera hispano-musulmana; en fin, integré en la realidad visible los datos sobre el modo en que los habitantes de aquellas montañas y valles expresaban sus devociones y festejaban sus tradiciones. El paisaje adquirió así la justa escala de su complejidad, se hizo más rico y por ello, mucho más atractivo. Y en la medida en que mis conocimientos se acrecentaban se iba haciendo preciso reducir el enfoque de mi doctorado, que acabó siendo un estudio sobre el elemento en el que siempre me pareció que todo se sintetizaba: el hábitat.

Muy pronto me salió al paso otra referencia básica: la del viajero inglés Julián Pitt Rivers, que nos había dejado un singular cuadro de situación del viejo diálogo que sostenían los hombres y aquel espacio serrano en los durísimos años de la posguerra. Pese a sus limitaciones, aquella obra fue importante porque complementaba los estudios de Jesús y José de las Cuevas y espe- 
cialmente porque me hablaba de la vida real, de los hombres que habitaban aquel terruño entonces tan inhóspito. Lo hacía de un modo parejo a como las obras del geólogo Juan Gavala contaban los secretos ocultos de sus roquedales y como mis posteriores y reiteradas incursiones por su bibliografía, de especial interés los estudios de G. Serrán Pagán, y por sus caminos me ponían en contacto directo con sus bosques relictos de pinsapos o con las legendarias historias de sus castillos y los vaivenes de una frontera centenaria, en torno a la cual se gestaron los procesos básicos de su poblamiento. $Y$ todo ello, de un modo que parecía más espontáneo que fruto de la reflexión, me fue conduciendo a la evidencia de que el hábitat serrano, los sorprendentes emplazamiento de sus núcleos, sus adaptación a las exigentes morfologías del territorio, la riqueza de sus formas, sus dispersos de caseríos o de molinos, en fin, todo aquello que de forma tan visible se evidenciaba en el paisaje, también era el reflejo de lo no visible y la síntesis certera de cuanto yo, desde el principio, había querido saber: el modo en que allí los hombres se relacionaban con la montaña.

Bajo la apariencia de uniformidad que parecía expresar el epígrafe de "pueblos blancos", fui detectando que en los núcleos de la sierra gaditana se encerraba una diversidad notable de emplazamientos y de formas. Abordé con entusiasmo el reto de saber por qué, y esto me descubrió una clave, elemental, pero no percibida por mí hasta entonces, indispensable para analizar los paisajes, a saber: que nada hay de azaroso en ellos, que cada elemento está donde está -y no en otro sitio-, por razones físicas o humanas que deben ser descubiertas. $Y$ en esas búsquedas y a lo largo de varios años, la realidad presente y pasada de la Sierra de Cádiz se me fue ofreciendo como una interminable sucesión de estímulos: pueblos en cumbres, como Torre Alháquime u Olvera, resbalando sus caseríos como un glaciar sobre la ladera; o pueblos en inexplicables hondonadas, como Setenil de las Bodegas y sus ejemplares de viviendas trogloditas; núcleos enriscados en pendientes incompatibles con la horizontalidad que la vida del hombre exige, como Zahara de la Sierra, junto a otros cómodamente recostados en el pie de monte, como Algodonales o El Bosque; la digna modestia jornalera de Alcalá del Valle o de El Gastor y la rancia nobleza de Grazalema, con los ecos aun visibles de su antigua opulencia. Tramas urbanas de tan clara herencia musulmana como sus topónimos, junto a otras de calles rectas, como Prado de Rey o Villamartín. Y al sur, la industriosa Ubrique, en el fondo de una depresión caliza, acogida y blanca en el envoltorio nido geológico, puerta de un sendero intermontano que nos enlazará con la quietud de Banaocaz y la sorpresa interior de Villaluenga del Rosario, frontera a una de las grandes simas kárticas que horadan esta porción de la serranía.

En los anchos espacios entre estos apretados y compactos núcleos se detectaba un poblamiento diseminado de modesta entidad que, en todo caso, no mermaba el interés de analizarlo. Esas casas dispersas son siem- 


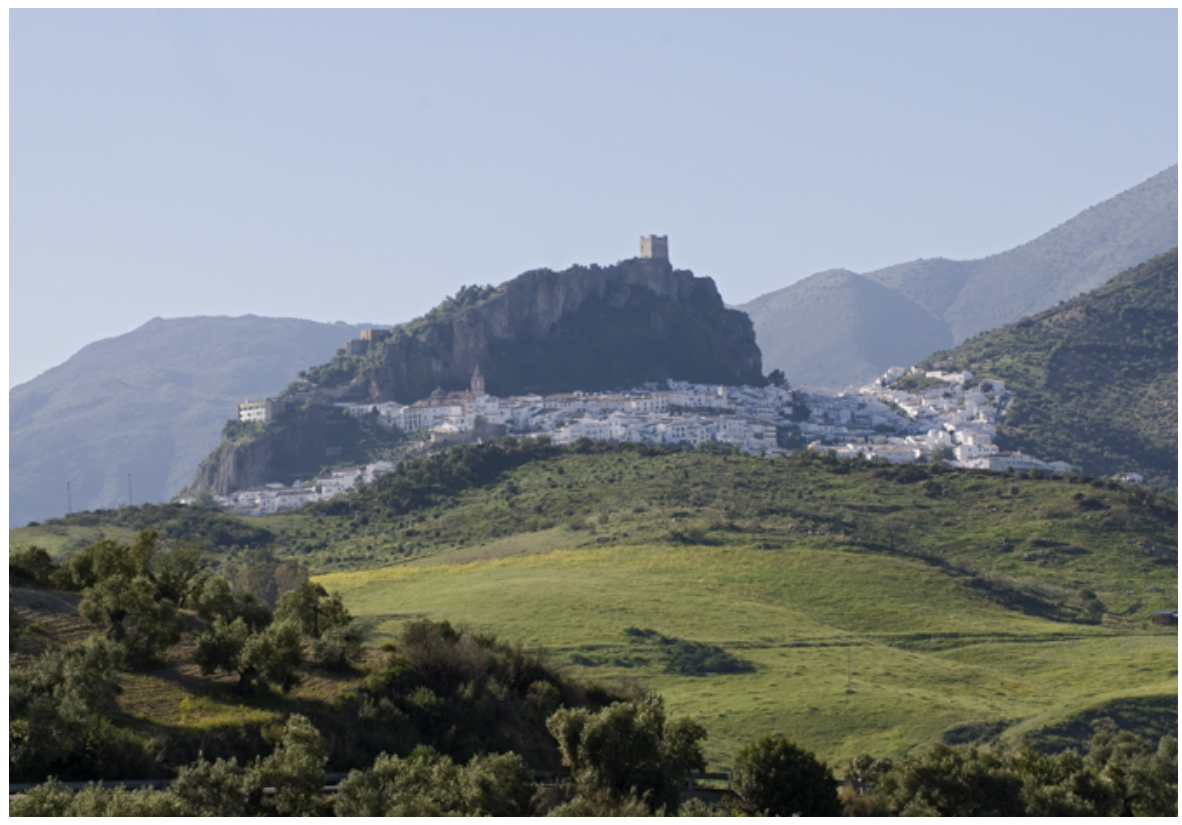

Vista general de Zahara de la Sierra (Cádiz) con castillo sobre ella | foto Fondo Gráfico IAPH (Juan Carlos Cazalla Montijano)

pre centros de gravedad y síntesis formal de la vida de los campesinos y/o ganaderos que las habitan, por seguir con las viejas, pero certeras, valoraciones del geógrafo A. Demangeón. Y por ello, reproducen modelos en los que alguna vez cristalizaron las experiencias de sus constructores. En la Sierra de Cádiz, eran los molinos en las áreas del olivar, alternando con casas con corralizas para los ganados en los ámbitos repulsivos para las prácticas agrarias. En algunas áreas próximas a cauces y arroyos, se erigían huertas con norias y, a veces, con telares varias veces centenarios que habían llegado hasta nosotros. Sobre ellos sí, el tiempo ha señalado su paso alentado por las dinámicas centrípetas de los habitantes y un consiguiente proceso de generales abandonos, prólogos de las desapariciones físicas de muchas de estas construcciones para las que las medidas protectoras llegaron demasiado tarde.

Pitt Rivers, el esbelto inglés que vivió la Grazalema de la postguerra, se quedó seducido por el aire de ensimismamiento de aquellas gentes serranas. Fruto quizás de los prolongados aislamientos a los que predisponen los ámbitos de montaña, o por tanto tiempo de caminos impracticables y lejanía a los focos urbanos gaditanos, fluía por los pueblos y aldeas una quietud sobrecogedora. Así también sorprendían aquellos espacios a aquel aprendiz de geógrafo que yo era en la mitad de los setenta y esas sensaciones han perdurado como parte de la memoria de mi relación con este territorio. Y tal vez por eso, también sus fiestas, religiosas o paganas, el Corpus de Zahara 


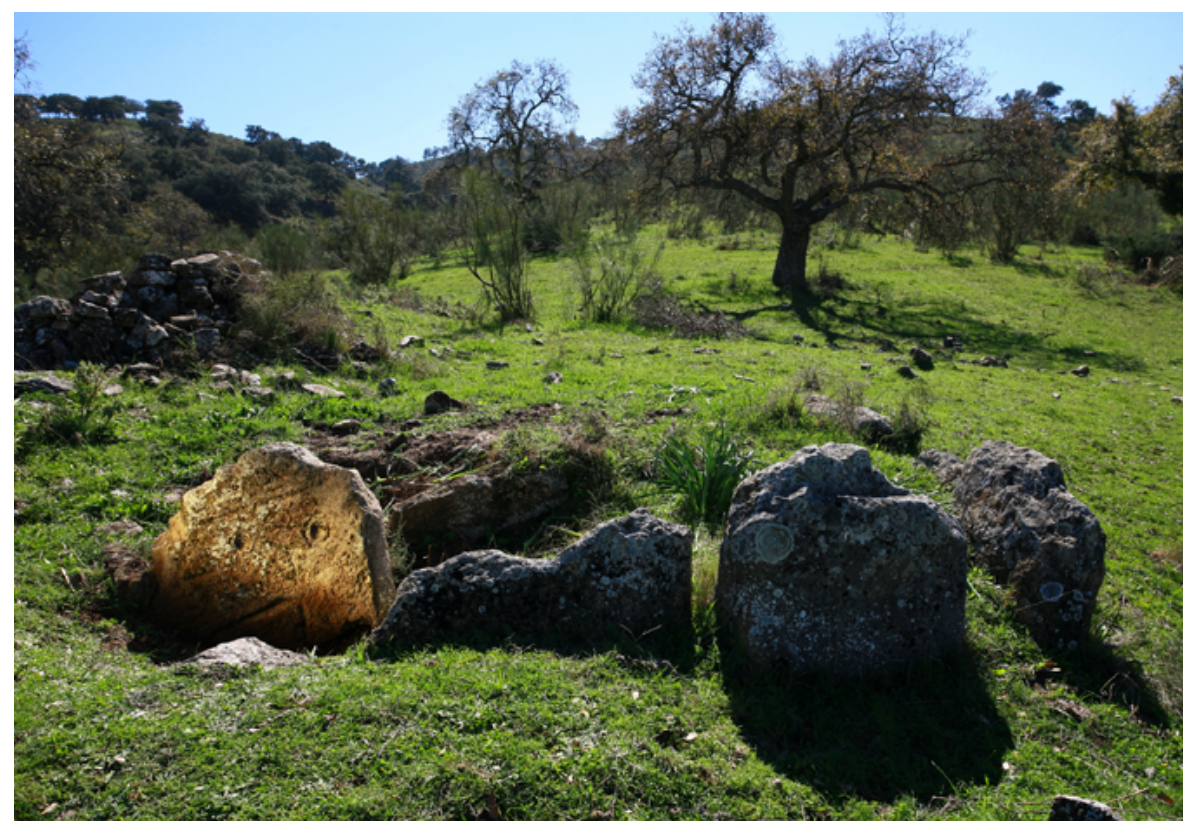

La estela de El Toconal en el interior del megalito. Olvera (Cádiz) | foto Fondo Gráfico IAPH (Miguel Ángel Blanco de la Rubia)

de la Sierra, el toro de Grazalema, la Semana Santa de Setenil, etc., siguen teniendo el emocionante pálpito de lo antiguo.

Pese a ello, en aquellos momentos ya habían comenzado a señalarse algunas nuevas visiones de la sierra que partían desde los procesos de expansión de los valores y usos urbanos. Por la vía del turismo, ofrecido como redentor de aquellos parajes, la ciudad se fue metiendo en la sierra gaditana, exigiéndole aquello que la sierra podía dar: ser objeto pasivo de esas iniciativas exógenas. Ahí comenzó un tiempo nuevo que hizo imprescindible la incorporación de los valores patrimoniales y las consiguientes medidas de protección. Muchas de ellas llegaron por vía de la protección ambiental -la creación del Parque Natural-, y todas ellas tras vencer resistencias movidas por los intereses y/o por la incredulidad de los afectados. Fueron tiempos en los que predicar los equilibrios no fue fácil en una tierra y para unas gentes cansadas de esperar, apegadas a la fuerza de costumbres seculares y reacias al cambio. Hoy es tiempo para poder aportar valoraciones y reconocer hasta qué punto el inmenso legado patrimonial -natural y cultural-, de la Sierra de Cádiz ha podido sobrevivir sin sobresaltos irreparables a las tensiones de las realidades contemporáneas. 


\title{
Reflexiones sobre los BIC conjuntos históricos: la Sierra de Cádiz
}

\author{
María Teresa Pérez Cano | Dpto. Urbanística y Ordenación del Territorio, Universidad \\ de Sevilla
}

URL de la contribución <www.iaph.es/revistaph/index.php/revistaph/article/view/3761>

\section{RESUMEN}

La tipología de inmuebles BIC conjunto histórico es la estrategia usada para salvaguardar los valores de las "unidades de asentamientos". Valores sobre los que cabe reflexionar, ya que al referirnos a construcciones urbanas 0 rurales debemos de entender que hablamos fundamentalmente de valores urbanísticos, paisajísticos y territoriales. Aunque en su formulación se recojan expresamente por "su interés histórico, arqueológico, paleontológico, artístico, etnológico, industrial, científico, social o técnico". Aspectos compartidos con otras tipologías de bienes inmuebles, especialmente con la de monumento, pero que dejan fuera expresiones como "formas de vida, cultura, actividades y modos de producción" asociadas a lugares de interés etnológico o "vinculados a modos de extracción, producción, comercialización, transporte o equipamiento" (LEY 14/2007: art. 26, tít. III), referidas a lugares de interés industrial. Para finalmente referirse exclusivamente al "valor de uso y disfrute para la colectividad y, en su caso, valores paisajísticos y ambientales, cuando define las zonas patrimoniales, añadiendo la idea de conjunto patrimonial, diverso y complementario" (LEY 16/1985: art. 15, tít. II).

Evidentemente lo patrimonial es complejo, pero esa literalidad de valores o limitación conceptual entre monumento y conjunto histórico hace que a veces se confundan, elevando lo arquitectónico al principal papel protagonista y diferenciándose principalmente en lo referido a su condición de lugar, esto es, "accidentes geográficos o estructura física representativa". Esta aportación, tomando como fondo los conjuntos históricos declarados de la Sierra de Cádiz, trata de analizar si estas declaraciones cumplen sus objetivos iniciales. Así mismo se intentará poner de manifiesto si las otras poblaciones que integran la sierra, serian merecedoras o no, de dicha protección.

\section{Palabras clave}

Bien de interés cultural | Cádiz (Provincia) | Conjuntos históricos | Sierra de Cádiz | Valores urbanísticos | 


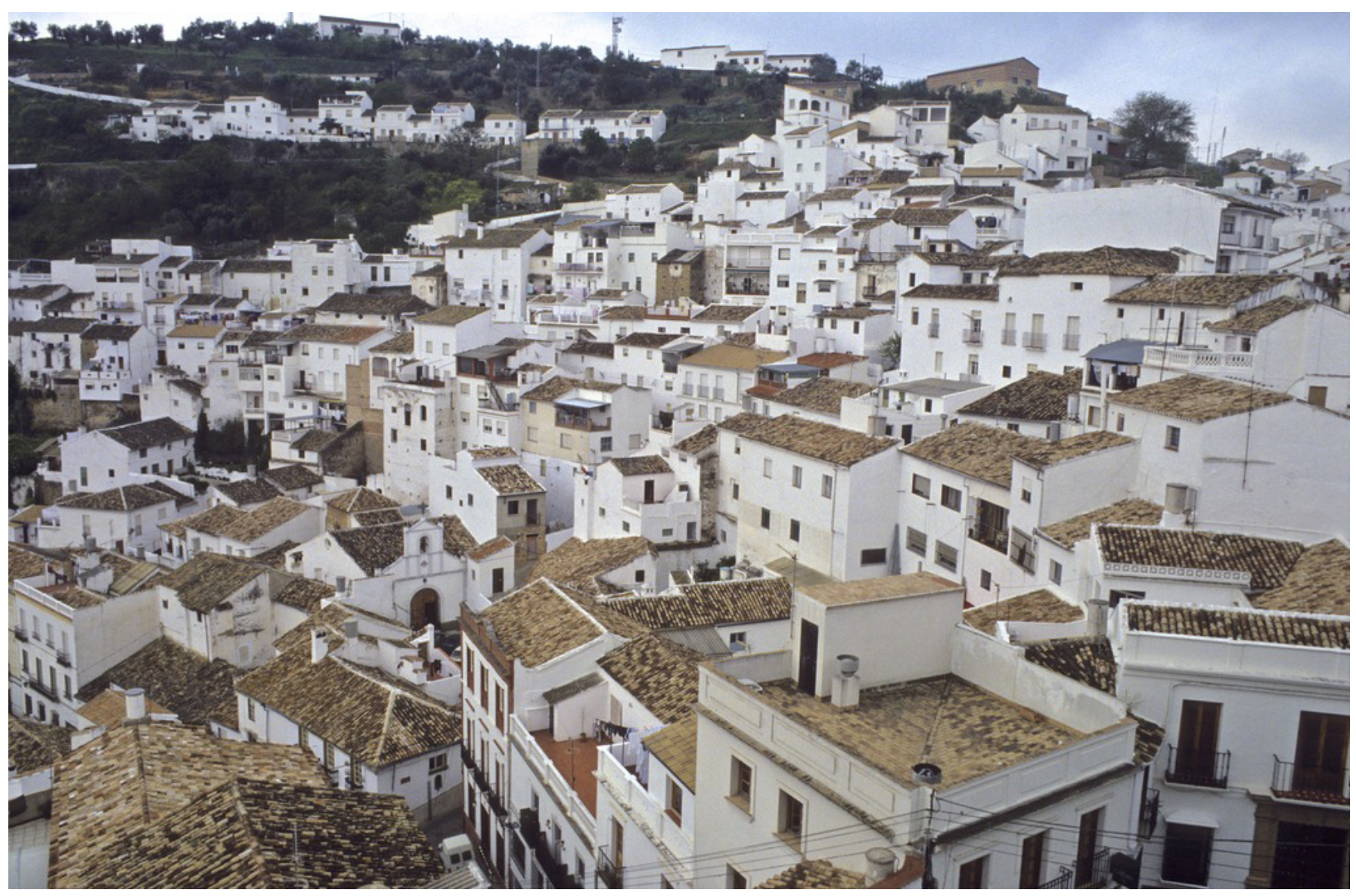

Ciudad histórica de Setenil de las Bodegas | foto Fondo Gráfico IAPH (Isabel Dugo Cobacho) 
1

Conjunto Histórico, en adelante $\mathrm{CH}$
1. Situación de la Sierra de Cádiz en el contexto de su provincia | elaboración propia (Clara Mosquera Pérez y María Teresa Pérez Cano) a partir de plano base de Cartoetsa. De todas las imágenes que ilustran este texto si no se indica lo contrario, en todas o alguna de las partes
El trabajo que se presenta al lector tiene como tema de estudio la Sierra de Cádiz y como objeto del mismo, sus conjuntos históricos. El objetivo principal es verificar si la declaración administrativa de estos bienes inmuebles como conjuntos históricos se ha hecho atendiendo a todo el potencial que tiene esta tipología patrimonial, o responde a una visión reducida de la misma, como respuesta a una valoración fundamentalmente arquitectónica.

La evolución en estos años en materia de patrimonio cultural pone a nuestro entender de manifiesto la limitación conceptual con la que desde sus inicios se concibió y definió la tipología de inmueble conjunto histórico. Bien es sabido que se pasó del edificio aislado a la ciudad, pensando siempre en claves de lo construido, del jardín a la catalogación urbanística del espacio público, incluso al ambiente urbano, incluyendo desde 1985 la idea de entorno. Pero podíamos preguntarnos si estos sumatorios de visiones parciales nos transmiten esa idea de ciudad completa, en todas sus complejidades y matices, a nivel individual como hecho urbano, y también formando parte de un sistema superior con capacidades de estratificar, jerarquizar y ordenar ámbitos territoriales tan distintos. Pensamos que esta visión más holística no ha sido tenida en cuanta en la definición de conjunto histórico ${ }^{1}$, y la Sierra de Cádiz es buen ejemplo de ello.

La provincia de Cádiz alberga un amplio territorio con paisajes diferentes que señalan su diversidad cultural. De sus cuarenta y cuatro municipios actua-

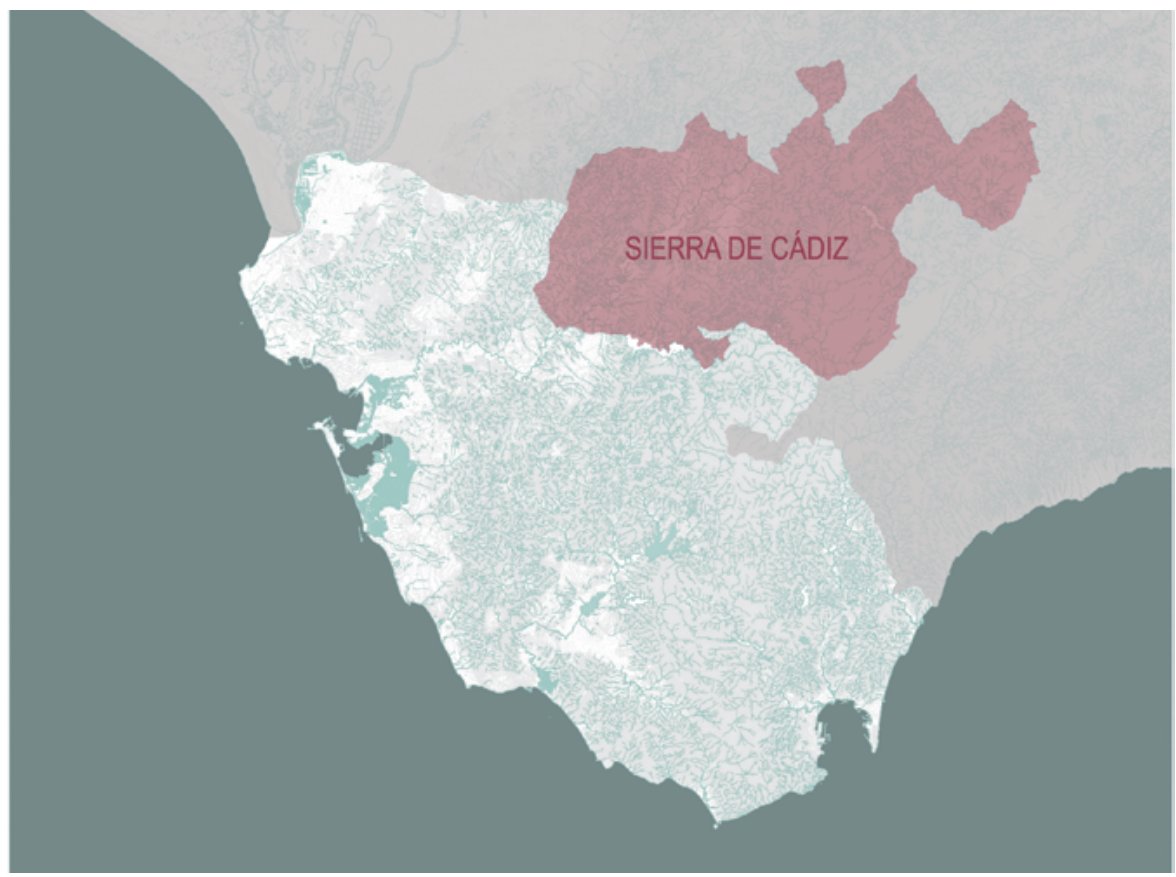


les, veintiséis son conjuntos históricos declarados. La conformación de la misma en el tiempo y en el espacio ha determinado su división administrativa actual en las denominadas comarcas: Litoral², Campiña, La Janda, Campo de Gibraltar y Sierra de Cádiz. Pero esta situación históricamente no ha sido siempre la misma, lo que deriva en escenarios urbanos distintos que nos señalan y explican la complejidad de este espacio secular.

De los cuarenta y cuatro municipios que en la actualidad componen la provincia, diecinueve ${ }^{3}$ (un 43,18\%) integran la Sierra de Cádiz y diez de ellos son conjunto histórico. Si los analizamos desde el punto de vista de la superficie que ocupa cada término municipal, vemos que ese porcentaje se concentra en algo menos del veintisiete por ciento del total de la provincia, exactamente el $26,85 \%$, lo que nos señala una de las características más relevantes de este territorio (planos 1 y 2 ).

Una comarca formada en su mayoría por pequeños municipios, donde el $\mathrm{CH}$ de Arcos de la Frontera, con un 7,09\%, de la superficie es la excepción ${ }^{4}$. En un siguiente escalón aparecen dos municipios: Villamartín $(2,85 \%)$ y el $\mathrm{CH}$ de Olvera (2,60\%); y, un poco más abajo, los $\mathrm{CH}$ de Algodonales $(1,80 \%)$, Espera $(1,66 \%)$ y Grazalema $(1,65 \%)$. El resto de los doce municipios restantes se deslizan entre el $0,36 \%$ del más pequeño, Algar, y el $1,11 \%$ del $\mathrm{CH}$ de Setenil de las Bodegas. De estos seis municipios mayores, un alto porcentaje, cuatro, es conjunto histórico. No es casual que a mayor tamaño, más protagonismo territorial.

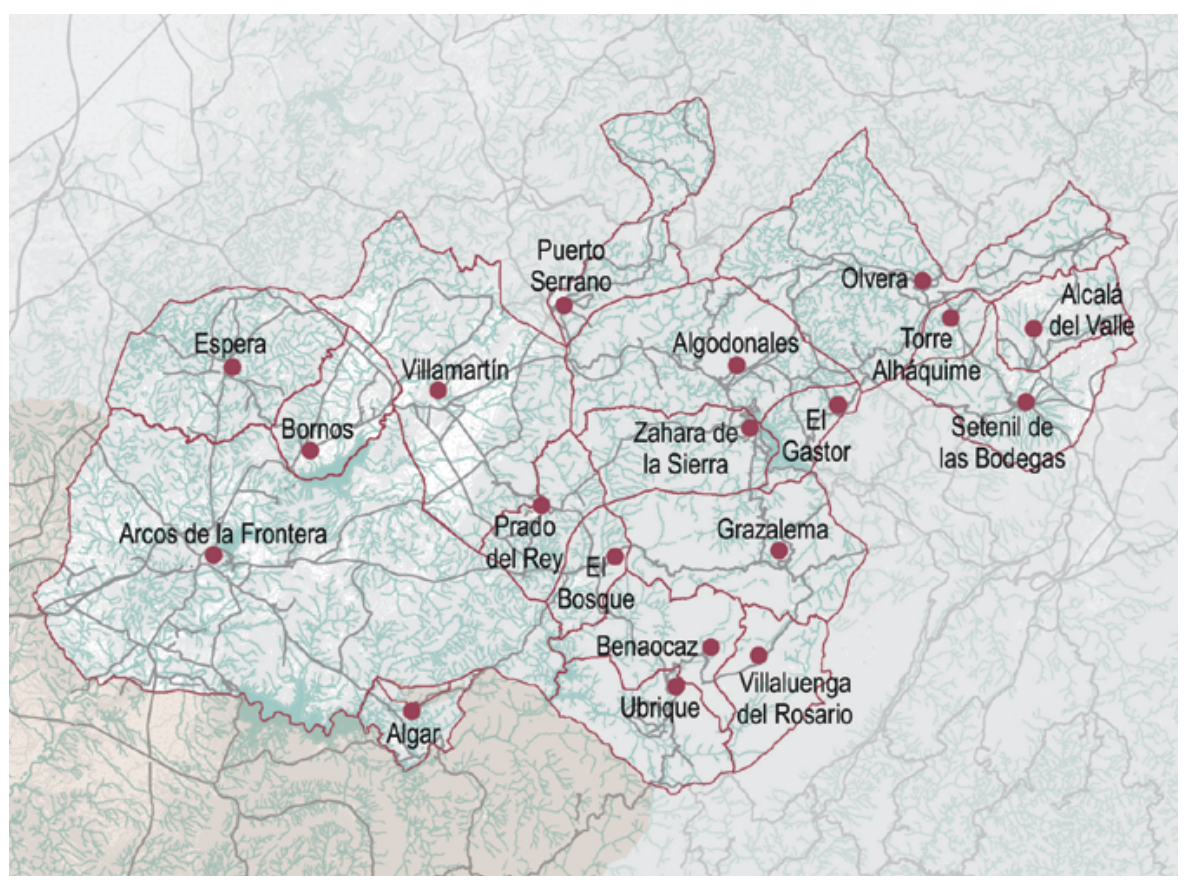

2

Aunque algunos historiadores como Juan Ramón Cirici Narváez o Alberto Ramos Santana, diferencian en la comarca Litoral dos sectores: Bajo Guadalquivir y Bahía de Cádiz. Ver La Provincia de Cádiz, Pueblo a Pueblo (AA. VV., 2000).

3

Por orden alfabético son: Alcalá del Valle, Algar, Algodonales $(\mathrm{CH})$, Arcos de la Frontera $(\mathrm{CH})$, Benamahoma, Benaocaz $(\mathrm{CH})$, Bornos $(\mathrm{CH})$, El Bosque, El Gastor, Espera, Grazalema $(\mathrm{CH})$, Olvera $(\mathrm{CH})$, Prado del Rey, Puerto Serrano, Setenil de las Bodegas $(\mathrm{CH})$, Torre Alhamique $(\mathrm{CH})$, Ubrique $(\mathrm{CH})$, Villaluenga del Rosario, Villamartín y Zahara de la Sierra $(\mathrm{CH})$.

4

Fuente: SIMA, Instituto de Estadística y Cartografía de Andalucía. 
Pero también cabría otra interpretación: ser un municipio de pequeña superficie puede indicarnos lo disputado que puede llegar a ser un territorio. Vaivén de fronteras, mostrar su capacidad de acogida de población a lo largo de los siglos..., características muy relevantes si hablamos de un territorio antropizado susceptible de ser patrimonializado.

Si tomamos el parcelario catastral urbano como referencia y sus relaciones morfotipológicas, autentico ADN de cada ciudad, podemos identificar los fragmentos de la misma con parcelarios más menudos, con los sectores más antiguos de la urbe, marcadamente funcionarizados, históricamente plenos de actividad. Ello ha condicionado el valor del suelo, por lo que, fruto de la tensión económica, el espacio se ha ido subdividiendo, afectando al parcelario e incluso al tamaño de las manzanas. Por contra, grandes parcelas en sectores de grandes manzanas, nos hablan de continuidad en la propiedad, de estabilidad funcional, de congelación de actividades e incluso de menor densidad de población. Situaciones intermedias, sea el caso del $\mathrm{CH}$ de Torre Alhamique, de homogeneidad morfológica y catastral, señalan la estabilidad en el tiempo y en el espacio de esta "unidad de asentamiento" (plano 3).

3. Delimitación del conjunto histórico de Torre Alháquime. Véase la forma de las manzanas y la configuración y tamaño de las parcelas | elaboración propia a partir del plano base: Decreto 70/2003, de 11 de marzo

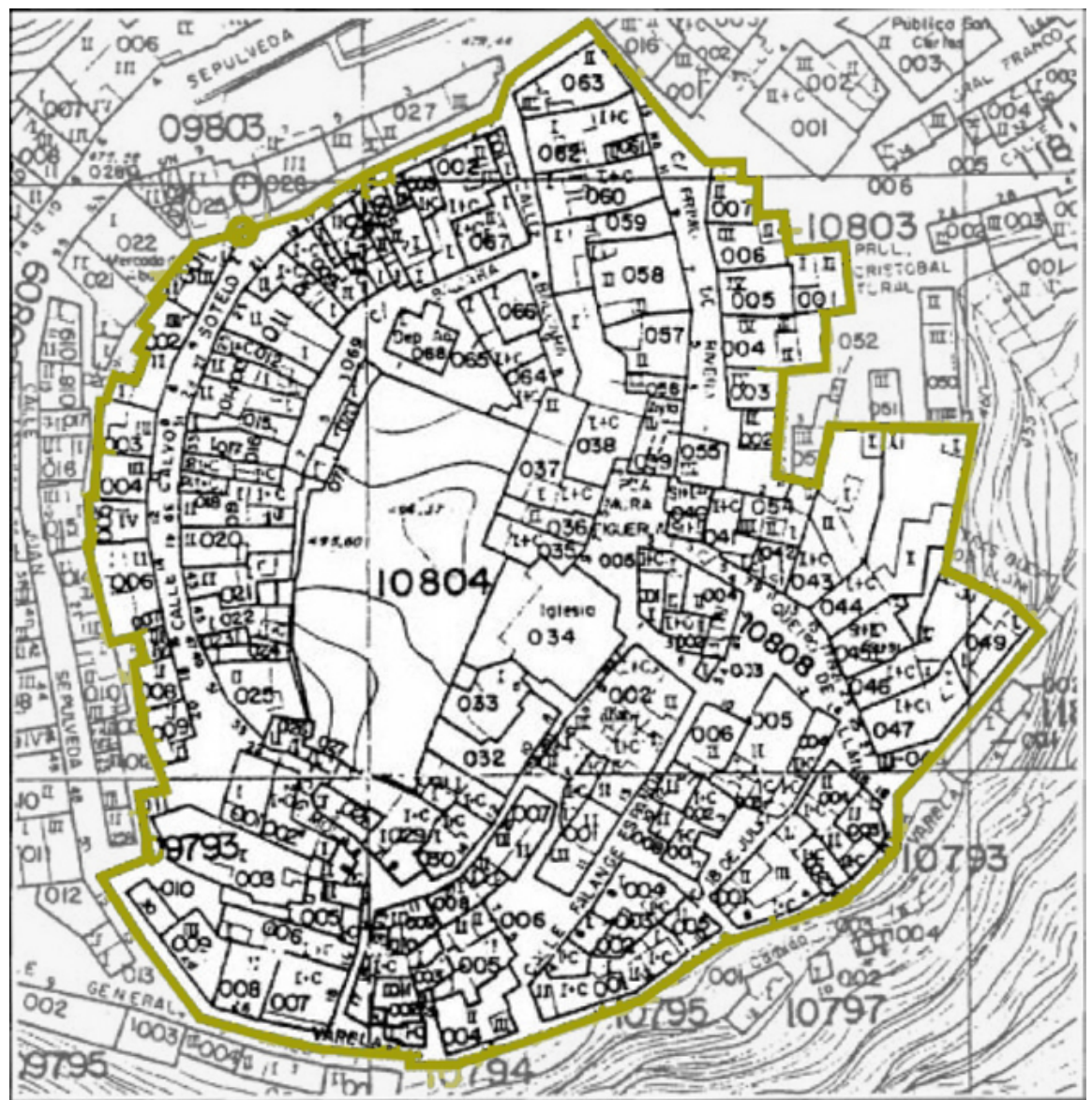



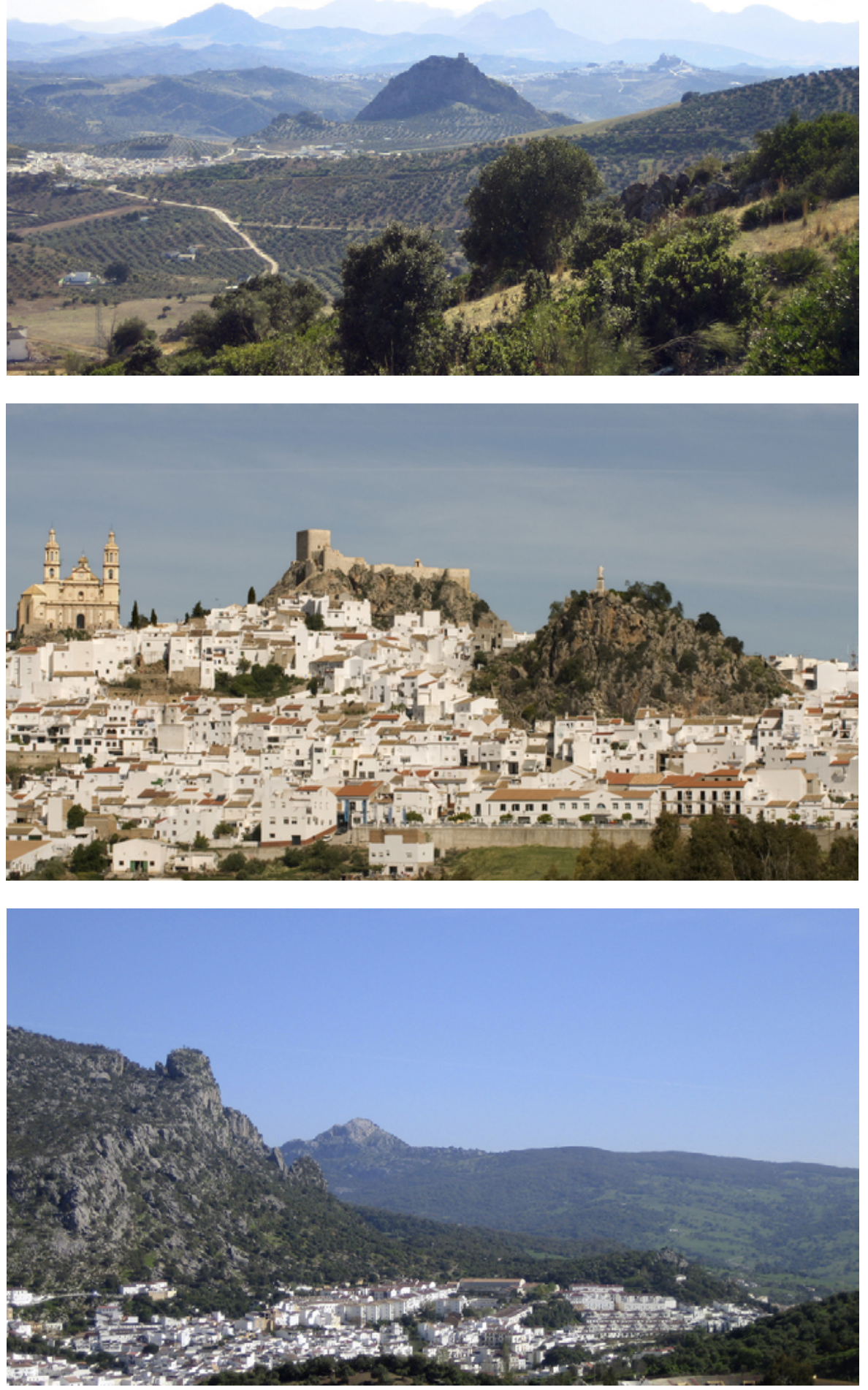

Ciudad Histórica de Zahara (110420044) | foto Fondo Gráfico IAPH (Esther López Martín)

Vista panorámica de Olvera (Cádiz) | foto Fondo Gráfico IAPH (Juan Carlos Cazalla Montijano)

Ciudad histórica de Ubrique | foto Fondo Gráfico IAPH (Esther López Martín) 
5

Plan de Ordenación del Territorio de Andalucía, aprobado por Decreto 206/2006 de 28 de noviembre.

\section{6}

Datos referidos a 2015. Fuente: SIMA, Instituto de Estadística y Cartografía de Andalucía.
Del Modelo Territorial de Andalucía recogido en el Plan de Ordenación del Territorio $^{5}$ (POTA), destacamos que nuestra comarca se encuentra entre los dominios territoriales del valle del Guadalquivir: Arcos, Bornos, Villamartín y Puerto Serrano; y el de las sierras y valles béticos: Prado del Rey, Ubrique, Algodonales, Olvera y Alcalá del Valle. Vemos que solo son nombrados por sus topónimos 9 de los 19 municipios, los que integran la red de ciudades medias de la comarca, siguiendo la jerarquía establecida en su sistema de ciudades, que deja fuera los asentamientos cuya población no supera los cinco mil habitantes.

En el caso que nos ocupa tenemos dos ciudades medias de segundo orden que actúan como cabeceras de la red: Arcos de la Frontera y Ubrique, ambas conjuntos históricos declarados; y otras dos: Villamartín y Olvera, esta última conjunto histórico, actuando como centro rural o pequeña ciudad 1, respectivamente. Las cinco restantes, Bornos, Puerto Serrano, Prado del Rey, Algodonales y Alcalá del Valle, lo hacen como centros rurales o pequeñas ciudades 2. De esta última serie, solo Algodonales es conjunto histórico (plano 4).

La población de la Sierra de Cádiz representa una de las densidades menores de entre las comarcas gaditanas, situándose en torno al 9,56\% sobre el total provincial ${ }^{6}$. Solo Arcos de la Frontera, con un $2,52 \%$, supera los treinta y un mil habitantes, ocupando el puesto número 10 de las ciudades más pobladas de la provincia. Le sigue a continuación Ubrique $(1,36 \%)$ con algo más de la mitad de población que el municipio anterior, aunque ya en el puesto número 18 del total provincial. Villamartín en el puesto 20 , con un $0,99 \%$, es el tercero de los municipios de la sierra, que se encuentra por encima de la media provincial.

Pero debemos señalar como rasgo más definitorio de esta comarca, en cuanto a población se refiere, que de los 44 municipios que componen la provincia gaditana, si los ordenamos por tamaño de población, encontramos que los 9 últimos de la lista, los menos poblados, pertenecen a la comarca de la Sierra de Cádiz. Cinco de los cuales son conjuntos históricos: Setenil de las Bodegas (0,23\%), Grazalema $(0,17 \%)$, Zahara de la Sierra $(0,12 \%)$, Torre Alháquime y Benaocaz, ambos con un $0,06 \%$ de la población provincial. Villaluenga del Rosario, con 471 habitantes (0,04\%) ocupa el último puesto de la lista. En definitiva, nos encontramos por tanto con una comarca que agrupa el $43,18 \%$ de los municipios de la provincia, en un $26,85 \%$ de superficie, con un $9,56 \%$ de población.

Si tomamos como referencia, la zonificación del POTA y sus unidades territoriales vemos que aparecen parcialmente agrupadas en la misma unidad territorial, dos provincias, Cádiz y Málaga, mediante la denominada serranías de Cádiz y Ronda. Son tres los conjuntos históricos que actúan como 


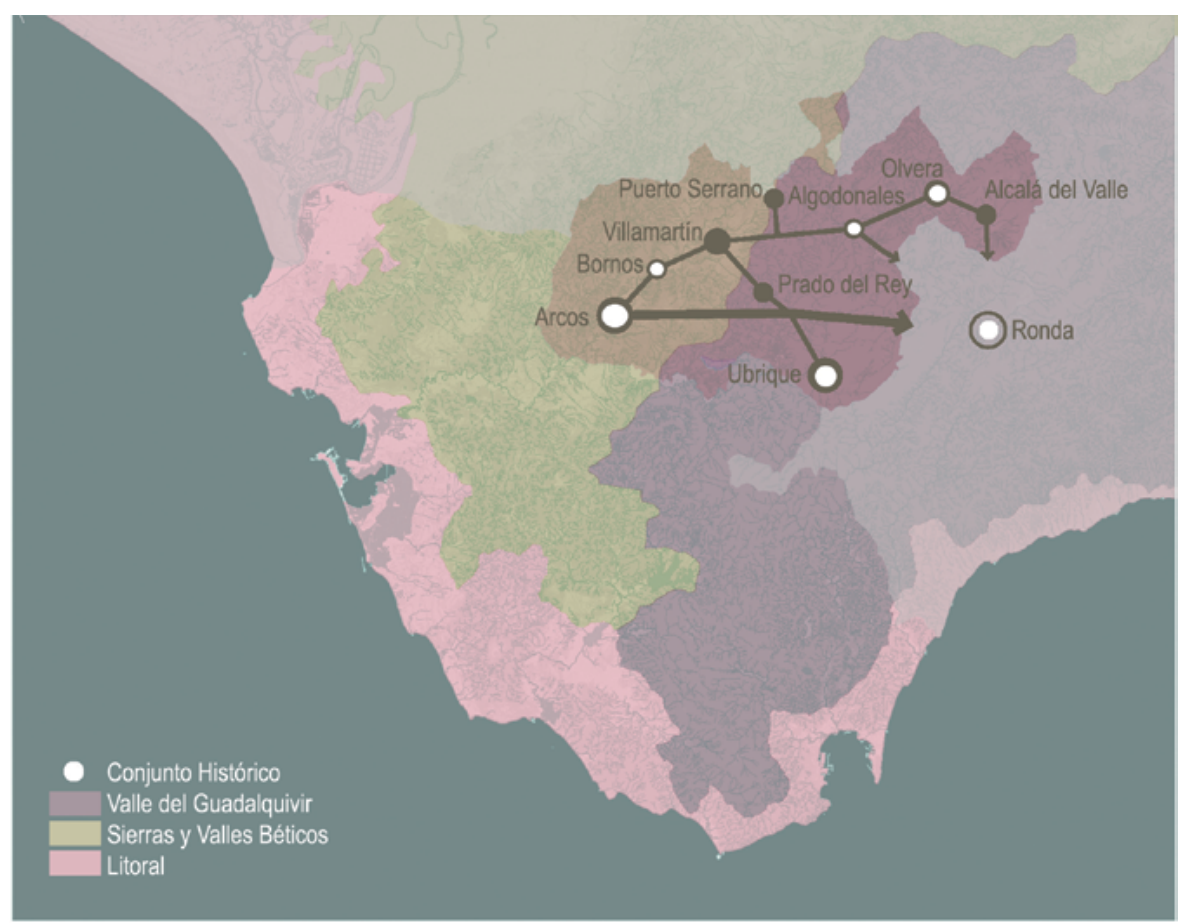

4. Concreción del Sistema de Ciudades de Andalucía en la Sierra de Cádiz | plano elaboración propia a partir del Modelo Territorial de Andalucía (POTA)

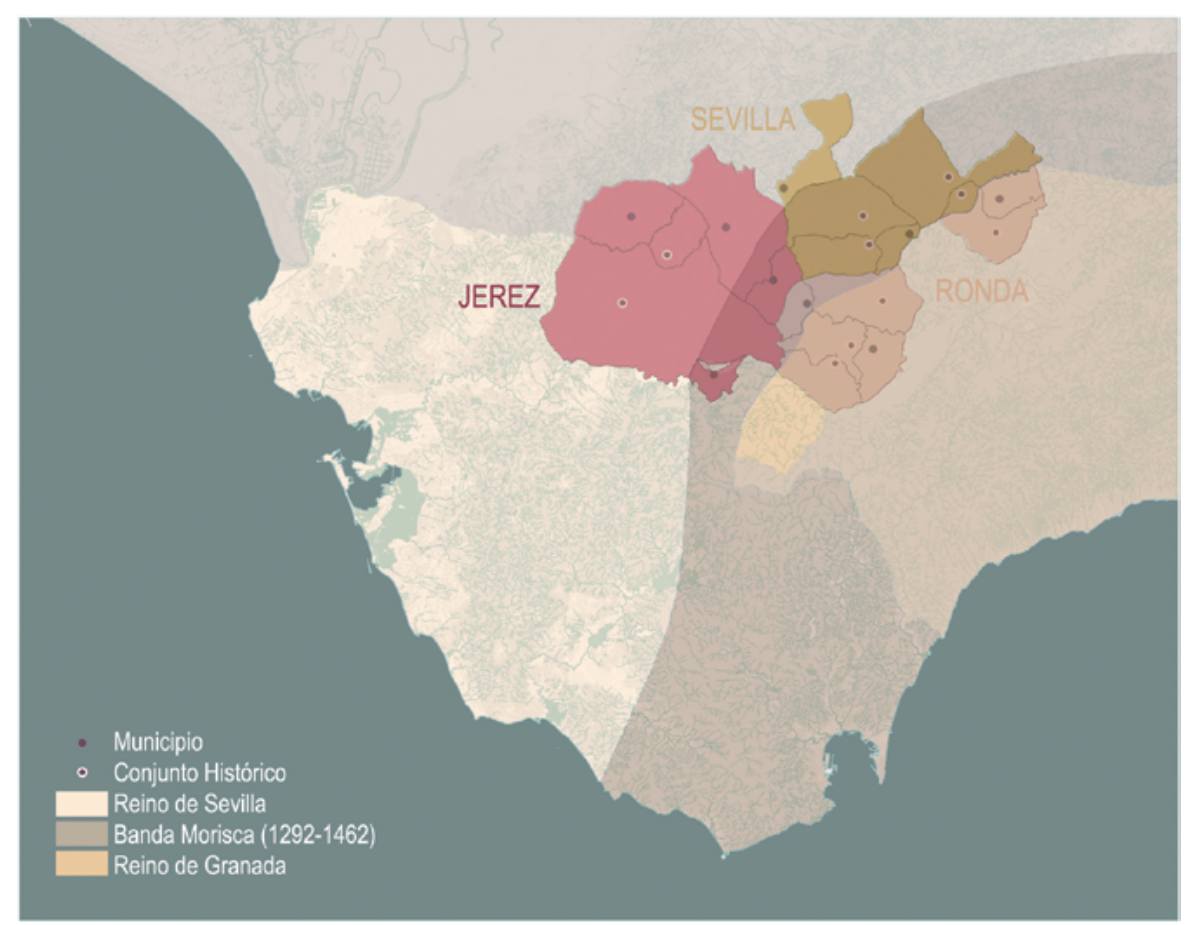

5. La importancia del espacio frontera entre el Reino de Sevilla y el Reino de Granada en la configuración de los conjuntos históricos de la Sierra de Cádiz. Se identifica en colores diferentes la procedencia según los históricos partidos judiciales de Jerez, Sevilla y Ronda 
7

Según el Catastro de Ensenada de 1749, Alcalá del Valle, Benaocaz, Grazalema, Setenil, Ubrique y Villaluenga del Rosario formaban parte de la provincia de Granada. Se puede consultar en el Catastro de Ensenada [en línea] <http://pares.mcu.es/Catastro/servlets/ ServletController> [Consulta: 22/2/2016].

\section{8}

El Reino de Sevilla se dividía en Cádiz, Campo de Gibraltar, Jerez de la Frontera, Sanlúcar de Barrameda y Sevilla. Ronda pertenecía al Reino de Granada. centros: Arcos de la Frontera, Ubrique y Ronda. Aunque el mayor protagonismo como ciudad media de primer orden lo asume Ronda, cuestión que tiene que ver con la trayectoria acontecida por estos municipios a lo largo de su historia.

Para situarnos, antes de la división provincial elaborada en tiempos de Carlos III por el conde de Floridablanca en 1789 (MADOZ, 1986: 63), la provincia de Cádiz procedía de los antiguos Reinos de Sevilla y Granada, siendo, sin duda, la Sierra de Cádiz el sector que más claramente compartía esta dualidad de orígenes ${ }^{7}$. Así mismo la división de los dos reinos en partidos provinciales nos sitúa en un espacio territorial fragmentado entre los ámbitos a los que pertenecían: Ronda, Jerez y Sevilla ${ }^{8}$. De los diecinueve municipios que constituyen la Sierra de Cádiz, formaban parte del partido de Ronda: Alcalá del Valle, Benaocaz, El Bosque, Grazalema, Setenil de las Bodegas, Ubrique, Villaluenga del Rosario. Del partido de Jerez: Algar, Arcos de la frontera, Bornos, Espera, Prado del Rey, Villamartín. Y del partido de Sevilla: Algodonales, El Gastor, Olvera, Puerto Serrano, Torre Alháquime, Zahara de la Sierra (plano 5).

Veremos cómo esta división territorial ha marcado su origen y destino como futuros conjuntos históricos. No debemos de olvidar que el proceso de cristianización, con diferencias de más de dos siglos en las conquistas de sus poblaciones, Arcos de la Frontera en el año 1264 y Alcalá del Valle 1484, han caracterizado el proceso de su poblamiento y posterior evolución.

Analizando las declaraciones comprobamos que de los siete municipios que procedían del antiguo partido judicial de Ronda, 4 son en la actualidad $\mathrm{CH}$. De los doce restantes integrados entre Jerez y Sevilla, la mitad son a día de hoy $\mathrm{CH}$. Pero cuáles son los valores señalados en la construcción de los "espesores patrimoniales" de los $\mathrm{CH}$ de la Sierra de Cádiz, que como capas de hojaldres nos ayudaran a entender su verdadero significado. Para responder a esta pregunta vemos necesario explicar cual ha sido la secuencia de su protección (plano 6).

El primer $\mathrm{CH}$ de la provincia de Cádiz en declarase fue Arcos de la Frontera en el año 1962, al amparo de la Ley de 13 de mayo de 1933 (LEY, 1933), por delante de ciudades como Jerez de la Frontera (1967), Sanlúcar de Barrameda (1972) o Cádiz capital (1973). Como sabemos, en esta primera etapa de la protección los valores histórico y artístico como elementos determinantes de la protección de un bien, serán los de mayor peso al declarar. Pasarán más de veinte años hasta que otros municipios se incorporen a la nómina de la protección (planos 7 y 8 ).

A lo largo de 1982, recién iniciada la andadura democrática y el estado de las autonomías, se incoan expedientes para la declaración de cinco muni- 

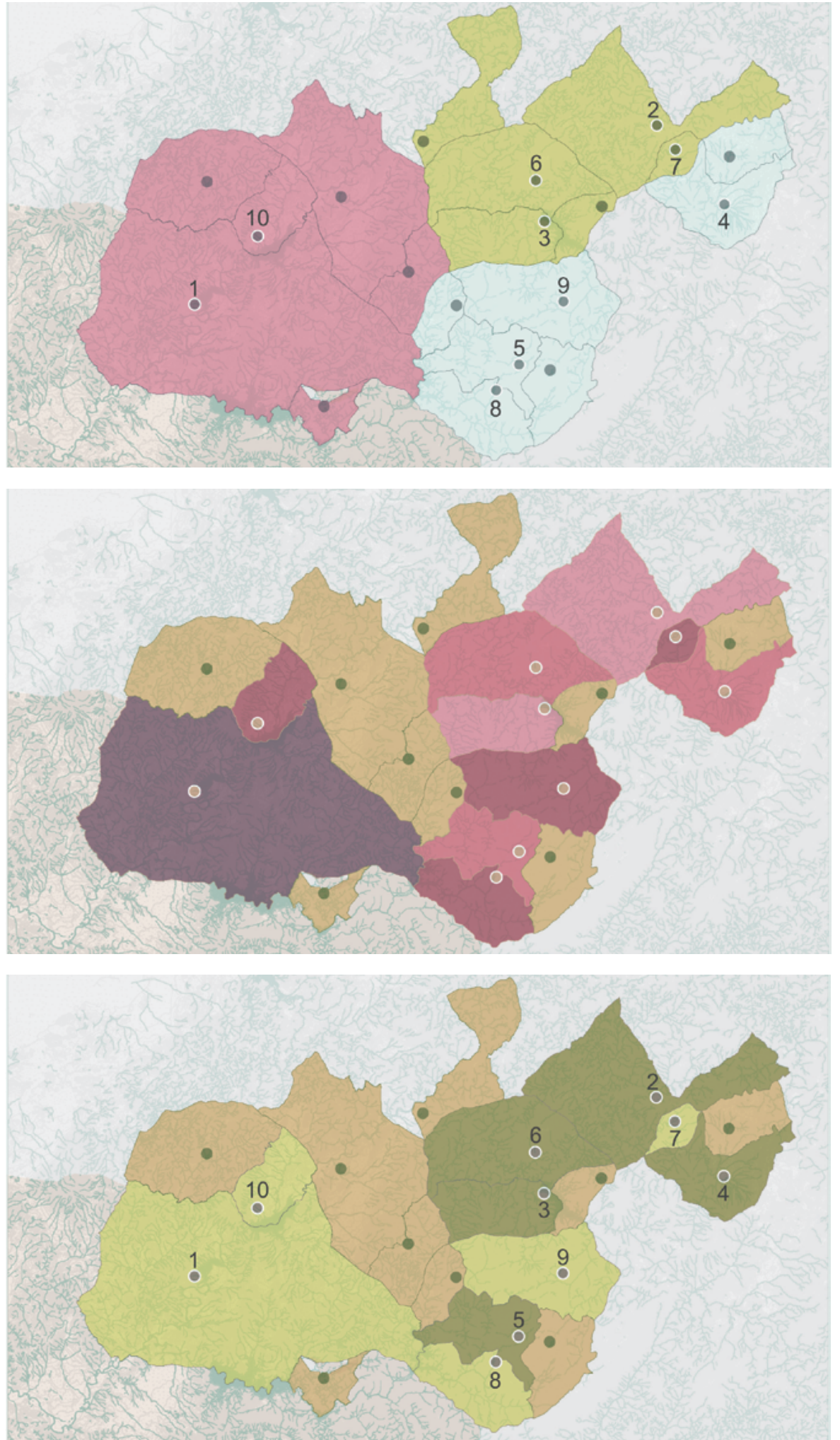

6. Secuencia en la declaración de los conjuntos históricos de la Sierra de Cádiz: 1. Arcos de la Frontera, 2. Olvera, 3. Zahara de la Sierra, 4. Setenil de las Bodegas, 5. Benaocaz, 6. Algodonales,7.

Ubrique, 9. Grazalema, 10. Bornos. Arcos de la Frontera ha ampliado en 2004 la delimitación de 1962. Se identifica en colores diferentes la procedencia según los históricos partidos judiciales de Jerez, Sevilla y Ronda

7. Zonificación por año de declaración, de los conjuntos históricos de la Sierra de Cádiz. En gama de rosas, de claro a oscuro: 1983, 1985, 2003 y 2004

8. Legislaciones de patrimonio vigentes en el momento de la declaración de los conjuntos históricos. Ley de 13 de mayo de 1933, en los casos de 2 Olvera, 3. Zahara de la Sierra, 4 . Setenil de las Bodegas, 5. Benaocaz, 6. Algodonales. Y Ley 16/1985 para los casos de 7. Ubrique, 9. Grazalema, 10. Bornos y 1 Arcos de la Frontera 
Puede consultarse cualquiera de los decretos cuyas fechas se ha señalado. cipios. Mediante informe aún de la Real Academia de Bellas Artes de San Fernando, y por decreto del entonces Ministro de Cultura Javier Solana se resuelven en 1983, aún como conjunto histórico-artístico, primero Olvera (13 de abril de 1983) y Zahara de la Sierra (20 de octubre de 1983). Dos años después, aún al amparo de la Ley de 13 de mayo del 1933, pero ya siendo Consejero de Cultura, Javier Torres Vela, se terminan los expedientes de Setenil de las Bodegas (22 de enero de 1985), Benaocaz (5 de febrero de 1985) y Algodonales (2 de mayo de 1985). Son decretos breves, donde solo se argumenta siempre con el mismo texto que "el citado conjunto reúne los méritos suficientes para merecer dicha declaración"9.

La Ley 16/1985 de Patrimonio Histórico Español, cambia este panorama, introduciendo una amplia panoplia de valores que se sumarán a los ya tradicionales. Situación que se mantiene, en materia de $\mathrm{CH}$, en las sucesivas leyes de patrimonio de Andalucía (LEY 1/1991; LEY 14/2007). Señalamos que como elemento diferenciador, solo hace especial referencia al emplazamiento geográfico, pero sus valores de protección, o sea "por su interés histórico, arqueológico, paleontológico, artístico, etnológico, industrial, científico, social o técnico" son los mismos que los de monumento.

El mismo concepto de inmueble encaja mejor con la idea de arquitectura, pero no funciona de igual manera con el propio hecho urbano de la calle, barrio o ciudad. Y menos aún cuando ésta es capaz de articular o es la razón de ser de todo un territorio.

Aunque para ser honestos hay que señalar que aunque explícitamente las leyes no indican para la tipología $\mathrm{CH}$ expresiones como formas de vida, cultura, actividades y modos de producción o vinculados a modos de extracción, producción, comercialización, transporte o equipamiento, o al valor de uso y disfrute para la colectividad y, en su caso, valores paisajísticos y ambientales, o la idea de conjunto patrimonial, diverso y complementario, en algunos de los ejemplos declarados en la Sierra de Cádiz, estas cuestiones se tienen en cuenta.

De esta etapa última son las declaraciones de Torre Alháquime, Ubrique, Grazalema y Bornos, así como la ampliación del $\mathrm{CH}$ de Arcos de la Frontera. En esta serie, encontramos por primera vez planos definitorios de las delimitaciones (plano 9) y, en el caso de Arcos, el único de los 10 $\mathrm{CH}$ de la Sierra que cuenta con entorno delimitado. En Arcos (DECRETO 105/2004) se señalan expresamente "(...) valores históricos, paisajísticos, urbanísticos, arquitectónicos y estéticos, así como enclave geográfico ha constituido en todos los tiempos un lugar estratégico. La protección de los valores histórico-artísticos, paisajísticos y estéticos, que sintetizan las particularidades del núcleo urbano, así como de las relaciones del Conjunto con su entorno (...)". 


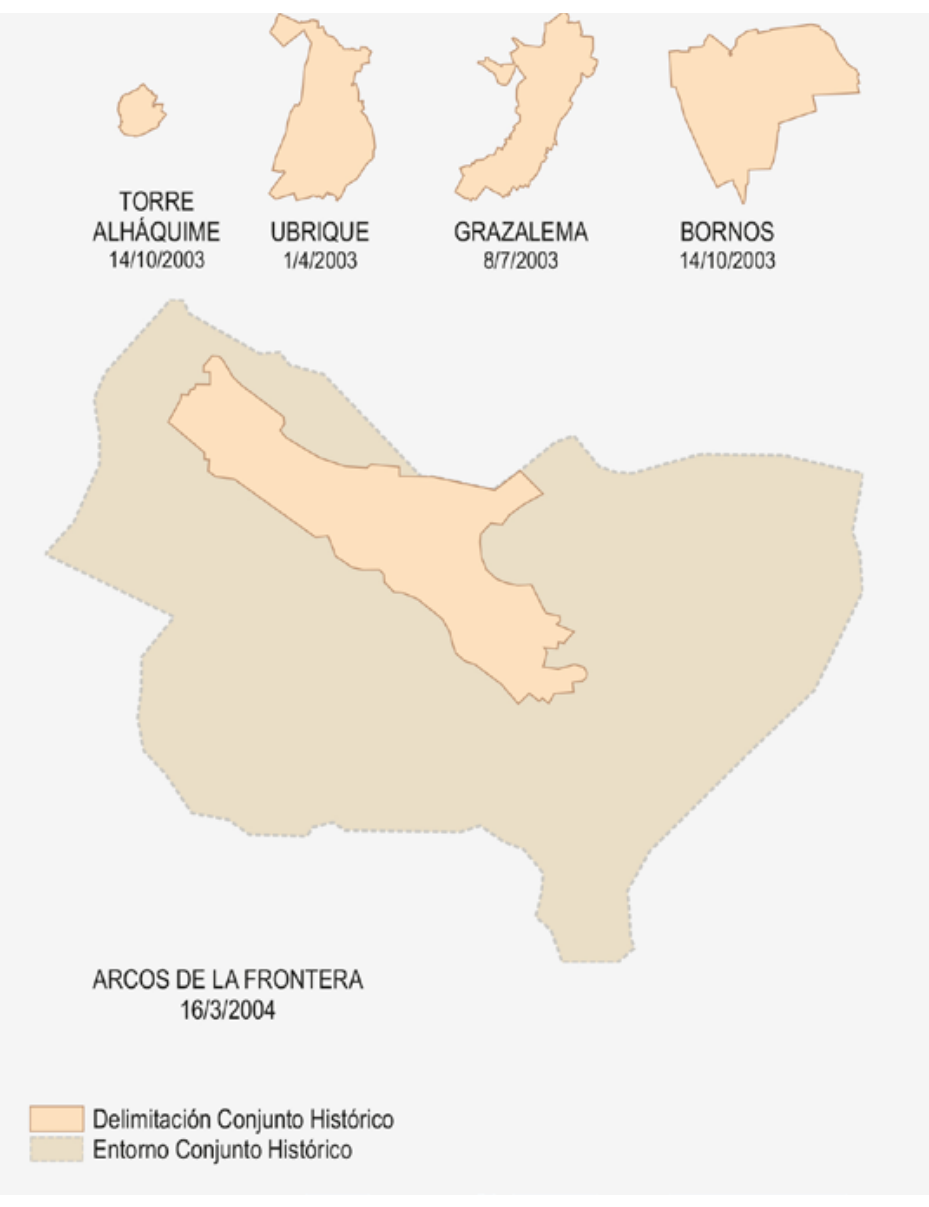

Finalmente nos planteamos qué sucede con los municipios que no han sido aún declarados. La definición de conjunto histórico no admite matices, se es o no se es. Esta situación que es una realidad legal general para todas las tipologías, no es del todo cierta pues, en el contexto de la gestión patrimonial urbanística, tipologías como la de monumento, admiten escalas de grises ya que puede escalonarse la protección en figuras intermedias, mediante el gradiente que nos proporciona la catalogación urbanística. En la tipología $\mathrm{CH}$ no existen categorías intermedias o inferiores. Esta carencia se intenta a veces solucionar, con el voluntarismo de la gestión administrativa, utilizando el concepto de entorno de bienes culturales de forma generosa, aprovechando alguna declaración en curso (plano 10). La idea de un "perímetro patrimonial básico" en situaciones intermedias podría favorecerse, al menos desde la redacción del planeamiento urbanístico.

Esta escala de grises, propicia lo que algunos autores denominamos la pirámide patrimonial ${ }^{10}$ de la protección, donde en la base se sitúan los bienes de menor relevancia y en la cima los bienes más excepcionales. ¿Cuál sería la de la Sierra de Cádiz? (plano 11).
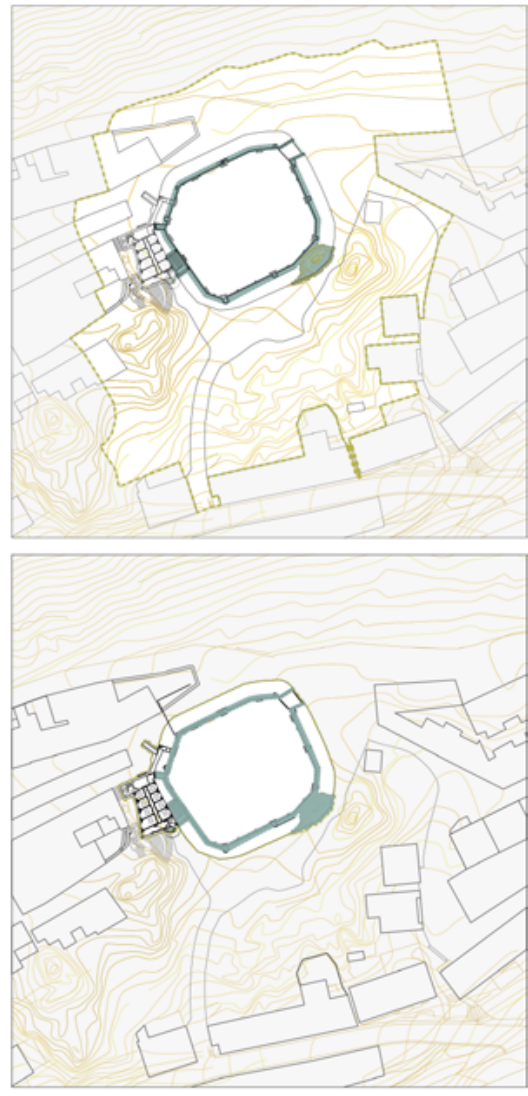

DELIMITACIÓN DEL BIC DELIMITACIÓN DEL ENTORNO DEL BIC

9. Conjuntos históricos cuya delimitación fue acompañada de la planimetría. Se han representado a la misma escala, para que se aprecie la gran diferencia de tamaño entre unos y otros | plano elaboración propia a partir de decretos declaratorios

10. Plaza de Toros de Villaluenga del Rosario Opciones de entornos estudiados en la realización del Expediente de Protección | plano base Hum 700. Imagen María Teresa Pérez Cano 
11. Municipios declarados conjunto histórico de la Sierra de Cádiz: 1. Arcos de la Frontera, 2. Olvera 3. Zahara de la Sierra, 4. Setenil de las Bodegas, 5. Benaocaz, 6. Algodonales, 7. Ubrique, 9. Grazalema 10. Bornos

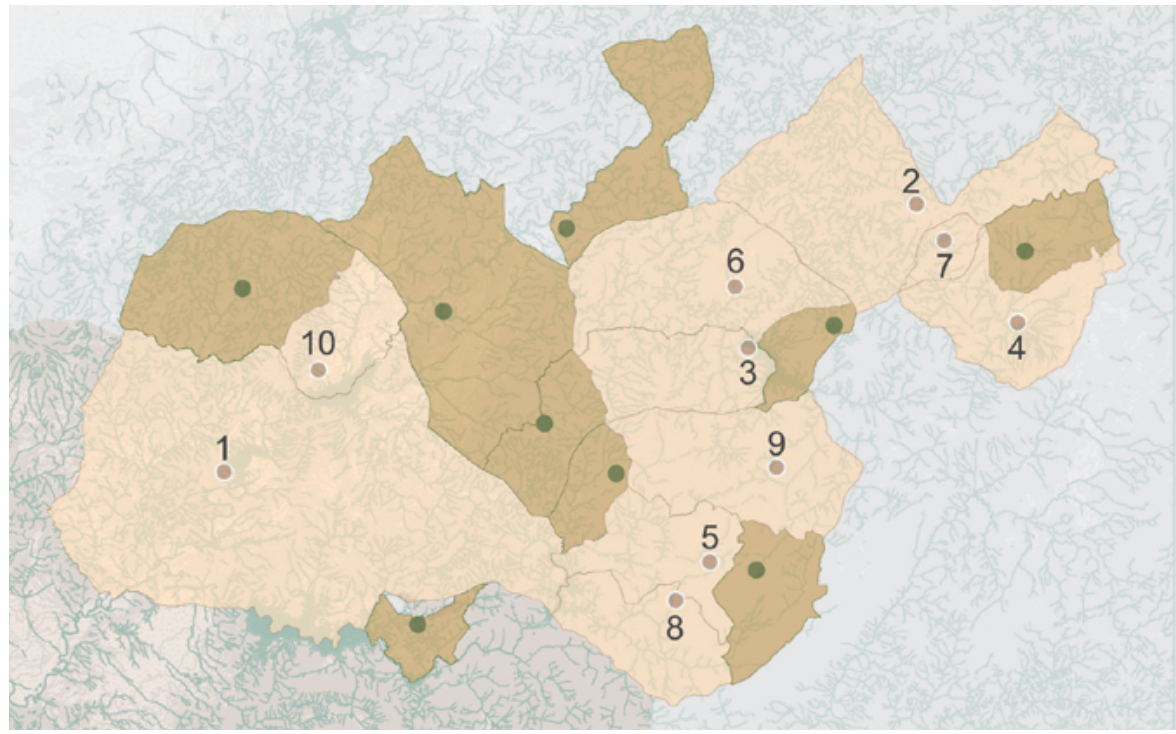

Villamartín es la tercera en población de la comarca, y la segunda en superficie, lo que siguiendo el criterio alegado en algunas declaraciones, sea el caso de Ubrique (DECRETO 91/2003) ' "(...) No obstante, la tensión constructiva de nuevas construcciones, derivadas del potente crecimiento económico de las últimas décadas, está empezando a alterar el perfil histórico que aún subsiste y que es necesario proteger (...)" corre cierto peligro. Conquistada en 1342, y reconquistada 1503, su pasado nos indica valores territoriales de frontera a considerar.

De lo que fuera provincia de Granada, destacan las inexplicables ausencias de Alcalá del Valle y Villaluenga del Rosario. En ambas podríamos encontrar características similares a las encontradas en Torre Alháquime "(...) conjunto con valor ambiental y adecuada escala de los espacios urbanos en relación con las construcciones. Su máximo interés se sustenta en los condicionantes físicos que han configurado su trama (...)" o Grazalema "La protección del legado histórico, artístico y particularmente etnológico, que ha mantenido una forma de vida basada en sistemas tradicionales, condicionado por su abrupta topográfica y por la distancia a cualquier núcleo de población importante, justifican plenamente su declaración como Bien de Interés Cultural (...)" (DECRETO 70/2003; DECRETO 208/2003).

Pero este acercamiento no sería completo si no se incluyesen propuestas para aquellos municipios que son ejemplo de nuevas fundaciones por repoblamiento, algunas cultas como Puerto Serrano (1615), y otras más recientes como El Bosque (1815) o El Gastor (1834) o incluso, la pedanía de Grazalema, Benamahoma insertada en la ruta de los Pueblos Blancos al igual que los diecinueve municipios analizados. En una etapa dónde la sostenibilidad forma parte del patrimonio, donde conceptos como el de resiliencia se va abriendo paso, pensamos que estos municipios merecerían otra consideración. 


\section{BIBLIOGRAFÍA}

- AA. VV. (2003) Territorio y patrimonio: los paisajes andaluces. Sevilla: Instituto Andaluz del Patrimonio Histórico, Consejería de Cultura, Junta de Andalucía, 2003 (Cuadernos; XV)

- AA. VV. (2002) Las Siete Villas de la Serranía de Villaluenga, 1502-2002. Frontera, repoblación señorial y patrimonio mancomunado en Andalucía. Ubrique, Cádiz: Fundación de las Siete Villas, 2002

- AA.VV. (2000) La Provincia de Cádiz, Pueblo a Pueblo. Cádiz: Industrias Gráficas Gaditanas, 2000

- AA.VV. (1994) Patrimonio y ciudad: reflexión sobre centros históricos. Sevilla: Instituto Andaluz del Patrimonio Histórico, Consejería de Cultura, Junta de Andalucía, 1994 (Cuadernos; V)

- BECERRA GARCíA, J. M. (2010) El patrimonio histórico y el planeamiento urbanístico en Andalucía. En El nuevo marco legal del patrimonio histórico andaluz. Sevilla: Instituto Andaluz de Administración Pública, 2010, pp. 3154

- DECRETO 91/2003, de 1 de abril, por el que se declara Bien de Interés Cultural, con la categoría de Conjunto Histórico, el sector delimitado a tal efecto de la población de Ubrique (Cádiz). Boletín Oficial de Estado, n. ${ }^{\circ} 133$, de 4 junio de 2013

- DECRETO 70/2003, de 11 de marzo, por el que se declara bien de interés cultural, con la categoría de conjunto histórico, el sector delimitado a tal efecto de la población de Torre Alháquime, en Cádiz. Boletín Oficial del Estado, n. ${ }^{\circ}$ 111, de 9 de mayo de 2003

- DECRETO 208/2003, de 8 de julio, por el que se declara bien de interés cultural, con la categoría de conjunto histórico, el sector delimitado a tal efecto de la población de Grazalema (Cádiz). Boletín Oficial del Estado, n. ${ }^{\circ} 230$, de 25 de septiembre de 2003

- DECRETO 105/2004, de 16 de marzo, por el que se amplía la delimitación del bien de interés cultural, con la categoría de conjunto histórico, de la población de Arcos de la Frontera (Cádiz), declarada Monumento HistóricoArtístico por Decreto que se cita. Boletín Oficial de la Junta de Andalucía, n. ${ }^{\circ}$ 74, de 16 de abril de 2004

- FARIÑA TOJo, J. (2000) La protección del patrimonio urbano. Instrumentos normativos. Madrid: Akal, 2000

- LEY de 13 de mayo de 1933 relativa al Patrimonio Artístico Nacional. Gaceta de Madrid, n. ${ }^{\circ}$ 145, 25 de mayo de 1933

- LEY 16/1985 de Patrimonio Histórico Español, de 25 de junio. Boletín Oficial de Estado, n. ${ }^{\circ} 155$, de 29 de junio de 1985
- LEY 14/2007 de Patrimonio Histórico de Andalucía, de 26 de noviembre. Boletín Oficial de la Junta de Andalucía, n. ${ }^{\circ} 248$ de 19 de diciembre de 2007

- LEY 1/1991 de Patrimonio Histórico de Andalucía, de 3 de julio. Boletín Oficial de la Junta de Andalucía, n. ${ }^{\circ} 59$ de 13 de julio de 1991

- MADOZ, P. (1986) Diccionario Geográfico-EstadísticoHistórico de Andalucía Cádiz. Valladolid; [Sevilla]: Ámbito: Ediciones Andaluzas Unidas, 1986 [Ed. facs.]

- PÉREZ CANO, M. T. (2015) Estrategias y retos en la docencia del patrimonio. La Dehesa. En Cuadernos de Transferencia Arquitectura y Patrimonio Histórico, HUM700US, Sevilla, 2015

- PÉREZ CANO, M. T. (2010) La protección del patrimonio desde el planeamiento urbanístico. III IAU I+D+I / 3.as Jornadas sobre Investigación en Arquitectura y Urbanismo, Madrid 17, 18 y 19 de junio de 2009, E.T.S.A., Universidad Politécnica de Madrid. Madrid: Mairea Libros, DL 2010

- PÉREZ CANO, M. T.; ESPINO HIDALGO, B. DEL; RAMILA ARJONA, R. (2013) Historic cities conservation throughout Cultural Heritage Laws: Andalusian Historic Areas. En $3^{\text {rd }}$ Annual International Conference on Architecture. 10-13 June 2013, Athens, Greece

- PLAN de Ordenación del Territorio de Andalucía, Decreto 206/2006 de 28 de noviembre. Boletín Oficial de la Junta de Andalucía, n. ${ }^{\circ}$ 250, de 29 de diciembre de 2006 


\section{Territorio y patrimonio arqueológico de la Sierra de Cádiz: un proyecto por concluir}

Luis Cobos Rodríguez | arqueólogo y director de la empresa ARQ Heritage Innovation URL de la contribución <www.iaph.es/revistaph/index.php/revistaph/article/view/3738>

\section{RESUMEN}

Territorio y arqueología de la Sierra de Cádiz constituyen un tándem de excelentes recursos patrimoniales, y un demostrado campo de acción de los agentes sociales y económicos para desarrollar programas que generen valor añadido en la oferta cultural y turística. El proyecto más significativo comenzó hace ya veinte años, denominado ruta arqueológica de los Pueblos Blancos y más tarde museo-territorio de la Sierra de Cádiz, que no culminó su última fase de gestión por diversos motivos. Sin embargo, nuevas perspectivas y estrategias pueden recuperar esta iniciativa y conseguir superar los retos del pasado.

\section{Palabras clave}

Cádiz (Provincia) | Desarrollo socioeconómico | Gestión cultural | Patrimonio arqueológico | Patrimonio cultural | Sierra de Cádiz | Territorio | 


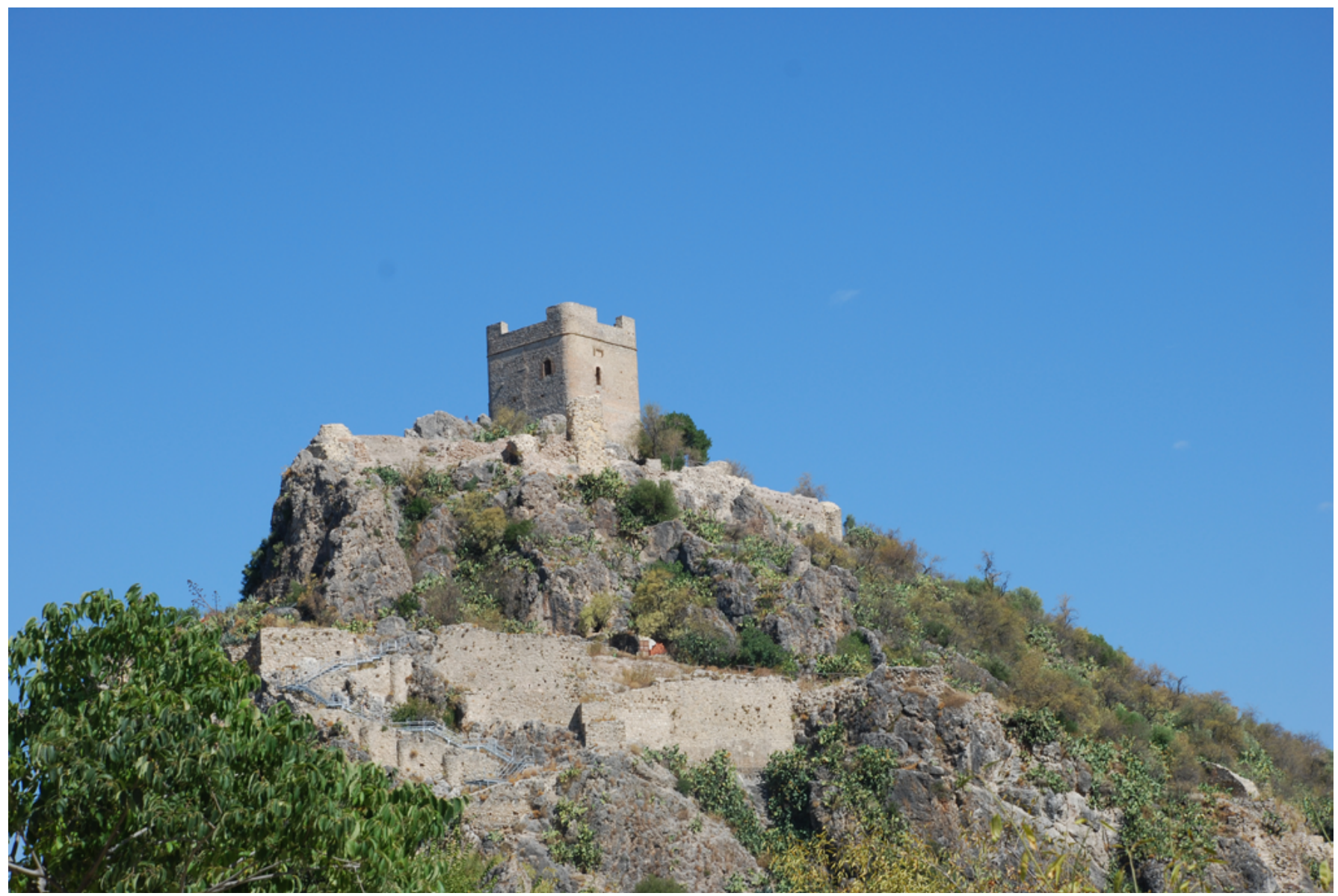

Villa medieval de Zahara de la Sierra | foto Luis Cobos 
En 1997 comenzó a construirse un proyecto de valorización del patrimonio arqueológico de la Sierra de Cádiz con el fin de dinamizar todo un territorio cultural y convertirlo en un auténtico museo al aire libre. Esta iniciativa, pionera en Andalucía en esos momentos, fue promovida por la Mancomunidad de Municipios de la Sierra de Cádiz y dirigida por los arqueólogos Luis J. Guerrero y el que escribe. Nuestro objetivo principal fue posicionar los recursos patrimoniales existentes para su explotación económica, su reconocimiento social y su uso cultural. Durante once años se trabajó para ello, con obstáculos y dificultades de todo tipo, hasta finalizar en 2007. La enrevesada gestión política del proyecto fue posiblemente la causa primordial de su finalización, sin embargo a día de hoy es factible recuperar la idea original, aprender de los fallos, pararse a pensar y ver con nuevas perspectivas y estrategias la recuperación de un proyecto que aún sigue vivo.

\section{PATRIMONIO TERRITORIAL}

Cuando hablamos de la Sierra de Cádiz desde el punto de vista territorial nos referimos a un espacio muy definido geográficamente que comprende un extenso territorio de más de dos mil kilómetros cuadrados, y que se sitúa en la parte nororiental de la provincia de Cádiz, lindando al norte con la provincia de Sevilla, al este con la de Málaga y al sur y al oeste con la comarca de la Campiña de Jerez. Aunque hablemos siempre de un territorio de sierra nos encontramos con una diversidad de realidades orográficas: por un lado, las zonas llanas de la campiña de la cuenca del Guadalete como continuación de la depresión del Guadalquivir (Arcos de la Frontera,

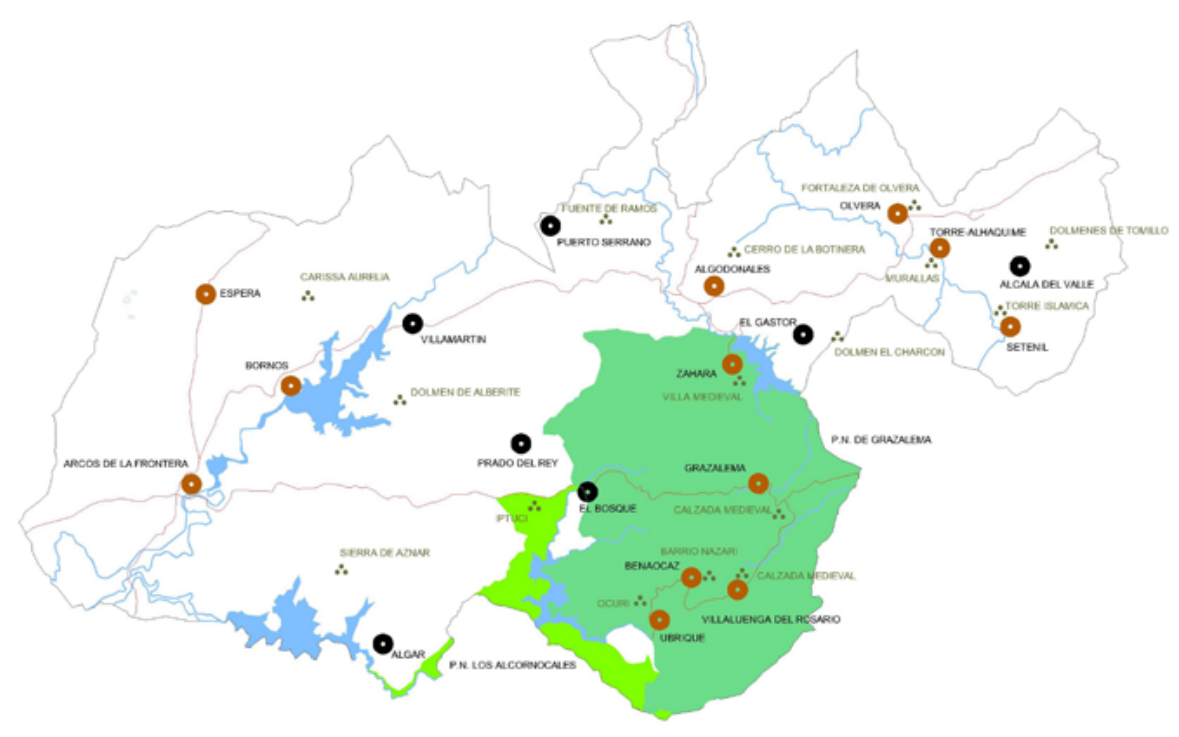

Sierra de Cádiz | mapa Consuelo Prados 
Bornos, Villamartín y Puerto Serrano); por otro, áreas más abruptas y con las elevaciones propias de la serranía que forman parte de la cordillera Bética, destacando en ella la sierra de Grazalema (El Bosque, Ubrique, Grazalema, Zahara de la Sierra, Ubrique, Benaocaz, El Gastor, Villaluenga del Rosario); y por último otras elevaciones de menor altura y valles interiores pertenecientes a la zona de las sierras Subbéticas (Algodonales, Olvera, Torre Alháquime, Setenil, Alcalá del Valle).

En este territorio es el río Guadalete el elemento aglutinador y unitario de la comarca que, además, sirve de nexo entre los diversos paisajes culturales, y que desde mediados del siglo XX modifica en parte el paisaje de la campiña con la construcción de los embalses de la cuenca: Arcos, Bornos y Zahara. Nace en Grazalema como río de montaña, con cauce estrecho y poco profundo, recibiendo aportes de otros cursos como el Gaidóvar, para después llegar a la campiña y recibir a su principal afluente, el Majaceite, también alterado por el embalse de Guadalcacín, configurando entre ambos los paisajes característicos de la Sierra de Cádiz (AA.VV., 1995: 29-37).

Contamos, además, con dos elementos de gran valor natural y cultural como son el Parque Natural de Grazalema (DECRETO 316/1984), con un paisaje kárstico de gran belleza paisajística; y el Parque Natural de los Alcornocales (LEY 2/1989), afectando, entre ambos, a los términos municipales de Grazalema, Zahara de la Sierra, El Bosque, Benaocaz, Villaluenga del Rosario, Ubrique, Prado del Rey, El Gastor, Arcos y Algar, ocupando un espacio de casi la mitad de la comarca. Otros espacios naturales protegidos son la Reserva Natural Complejo Endorréico de Espera, el Paraje Natural

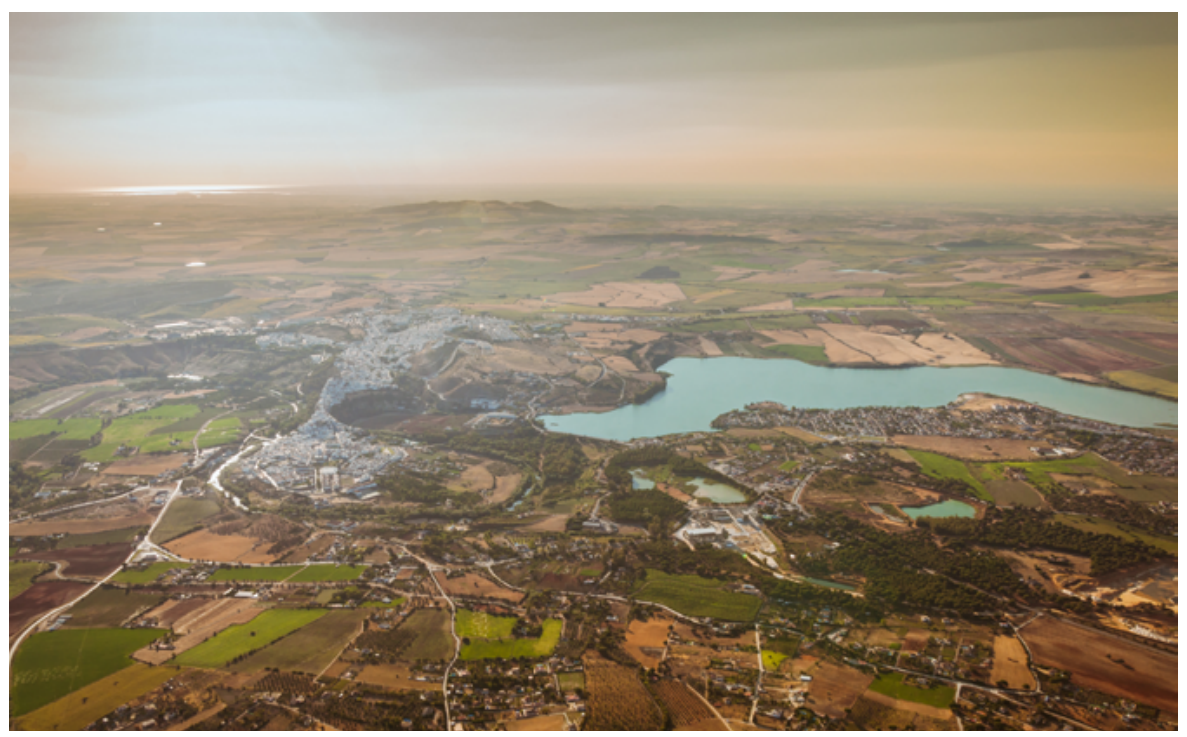

Campiña, el río Guadalete (embalse) a su paso por Arcos de la Frontera | foto Manu García 
1

Los conjuntos históricos BIC son Arcos de la Frontera, Algodonales, Benaocaz, Bornos, Espera, Grazalema, Olvera, Setenil, Torre Alháquime, Ubrique, Villaluenga del Rosario y Zahara de la Sierra.

\section{2}

La Ley $16 / 1985$, de Patrimonio Histórico Español de 25 de junio de 1985 señala en la Disposición Adicional Segunda que "Se consideran asimismo de Interés Cultural y quedan sometidos al régimen previsto en la presente Ley los bienes a que se contraen los Decretos de 22 de abrilde 1949, 571/1963 y 449/1973".
Cola del Embalse de Bornos, el Paraje Natural Cola del Embalse de Arcos de la Frontera y el Paraje Natural Peñón de Zaframagón.

Un total de 19 municipios, con una población cercana a los 120.000 habitantes pero con contrastes cuantitativos entre las diferentes poblaciones. La de mayor población está en zona de campiña (Arcos de la Frontera con 31.250 hab.) y la más baja en la serranía (Villaluenga del Rosario con 456 hab.). Posee la comarca 43 bienes de interés cultural $(11,19 \%$ de la provincia de Cádiz), de los cuales doce son conjuntos históricos declarados (CATÁLOGO, $2013)^{1}(63 \%$ de la comarca); otros dos son yacimientos arqueológicos (Iptuci y Carissa Aurelia) y todos los castillos y fortalezas, por el Decreto de 22 de abril de 1949 sobre Protección de Castillos Españoles, expedido por el Ministerio de Educación Nacional².

Por tanto, nos encontramos ante una serie de elementos naturales y otros de construcción humana que conforman un paisaje singular en constante evolución: ríos y embalses; vías de comunicación; campiñas, valles y sierras; parques, parajes y espacios naturales protegidos de gran valor medioambiental y ecológico; diecinueve localidades denominadas como Pueblos Blancos desde los años sesenta por el Ministerio de Turismo; un patrimonio cultural que incluye bienes inmuebles (iglesias, ermitas, monasterios, castillos, torres, fortalezas, pósitos, cillas, cortijos, molinos, santuarios, fuentes, lavaderos...), yacimientos arqueológicos, y una gastronomía, artesanía singular y un conjunto de prácticas, representaciones, expresiones, conocimientos y habilidades de su patrimonio intangible que le aporta una identidad propia $y$, por supuesto sus ciudadanos, verdaderos protagonista de su presente y futuro, y responsables de mantener su pasado.

Este es el presente del territorio de la Sierra de Cádiz, el contenedor a lo largo de la historia de un patrimonio cultural de indudable valor histórico, científico y simbólico, y de una potencialidad educativa y turística de gran alcance. Sin

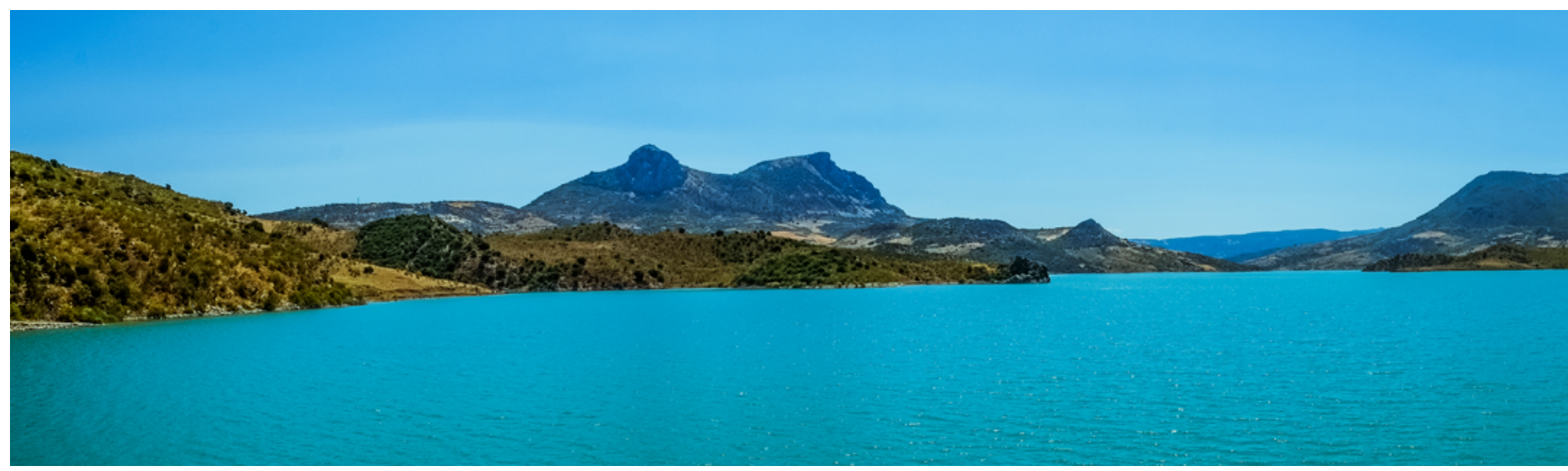


embargo, el territorio ha pasado de ser un simple escenario y soporte de un colectivo y de su patrimonio cultural a ser protagonista, a considerarse también como un recurso patrimonial, objeto de estudio de los investigadores y campo de acción de los agentes sociales y económicos, así como de las instituciones que dirigen y diseñan políticas culturales (CARAVACA BARROSO; FERNÁNDEZ SALINAS, 2005: 5-18). Un territorio amplio, disperso y que constituye un espacio donde se han desarrollado iniciativas patrimoniales, especialmente, en el patrimonio arqueológico.

\section{ANTECEDENTES}

En este territorio, y a través de políticas de fomento del empleo y de recuperación de bienes culturales y naturales, se han llevado a cabo una serie de proyectos, algunos inacabados, que podemos considerar vinculados a la intervención en el paisaje de la Sierra de Cádiz, desde una visión patrimonial y sobre todo desde la arqueología.

Una de las iniciativas de mayor envergadura y proyección fue la conocida ruta arqueológica de los Pueblos Blancos, desarrollada por la Mancomunidad de Municipios de la Sierra de Cádiz, donde el territorio pasó a ser de manera práctica un recurso patrimonial en sí, que sumado al patrimonio arqueológico constituyó una relevante actuación en el paisaje. Este proyecto que nace desde la arqueología se convirtió en una verdadera propuesta de intervención integral en el patrimonio cultural de la Sierra de Cádiz ${ }^{3}$.

Hasta mediados de los noventa las intervenciones arqueológicas se reducían a actuaciones puntuales en algunos de los yacimientos de la Sierra de Cádiz, sin ninguna o escasa proyección social. Es en 1993 cuando se inicia un proyecto general denominado Intervenciones en áreas de interés turístico cultural de la Sierra de Cádiz, promovido por el INEM, la Diputación de Cádiz
3

Iniciativa codirigida por Luis Javier Guerrero Misa y Luis Cobos Rodríguez.
Zahara, sierra del Pinar, monte Algarín y la cima de las Grajas | foto Manu García 
y la Consejería de Cultura de la Junta de Andalucía, en el que se incluían actuaciones de puesta en valor en algunos yacimientos arqueológicos, como la calzada romano-medieval de Ubrique a Benaocaz, la ciudad romana de Iptuci, la villa medieval de Zahara de la Sierra, entre otros bienes patrimoniales (COBOS RODRÍGUEZ, 2003: 10).

Poco tiempo después la Mancomunidad de Municipios de la Sierra de Cádiz apostó, desde mediados de 1996, por la aplicación de programas que tenían como objetivo la rentabilización social, económica y cultural de su rico patrimonio histórico y arqueológico. Estos programas se encuadraban en el ámbito de las nuevas políticas de empleo y desarrollo sostenible auspiciadas por la Unión Europea, en su incesante búsqueda de nuevos yacimientos de empleo. La denominación genérica de los mismos se enmarcó bajo el epígrafe de Recuperación y puesta en valor de los yacimientos arqueológicos de la Sierra de Cádiz (GUERRERO MISA; COBOS RODRÍGUEZ, 2002: 125). En estos momentos iniciales, el ámbito de actuación en la propia sierra se limitó a tan sólo cinco yacimientos arqueológicos claves, situados en otros tantos municipios serranos: Sierra Aznar en Arcos de la Frontera; la ciudad romana de Carissa Aurelia en Espera; la ciudad romana de Ocuri en Ubrique; el dolmen de Alberite en Villamartín; y la villa medieval de Zahara de la Sierra. En todos ellos se habían realizado intervenciones arqueológicas de urgencia en los últimos veinticinco años. Es a partir de 1998 cuando todos los programas emprendidos en este sentido se aglutinaron, de forma genérica, bajo el epígrafe Ruta Arqueológica de los Pueblos Blancos (GUERRERO; COBOS, 2002: 122).

Ya en el año 2000 se amplió a un total de 19 el número de yacimientos que comprendía la ruta, más por motivos políticos que técnicos (GUERRERO

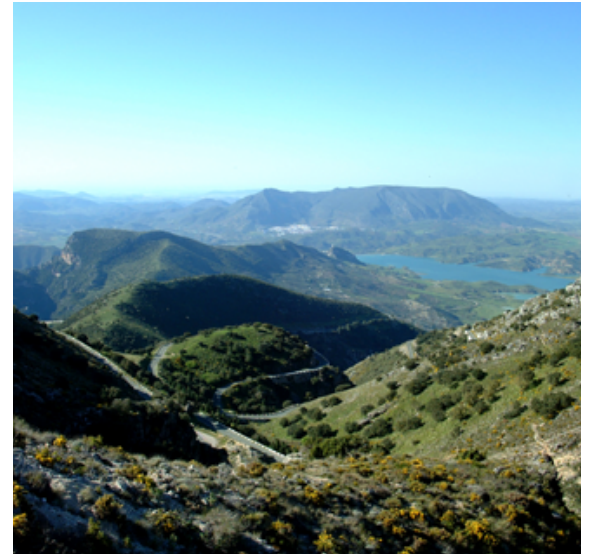

Zahara y Algodonales desde el puerto de las Palomas | foto Mancomunidad de Municipios de la Sierra de Cádiz

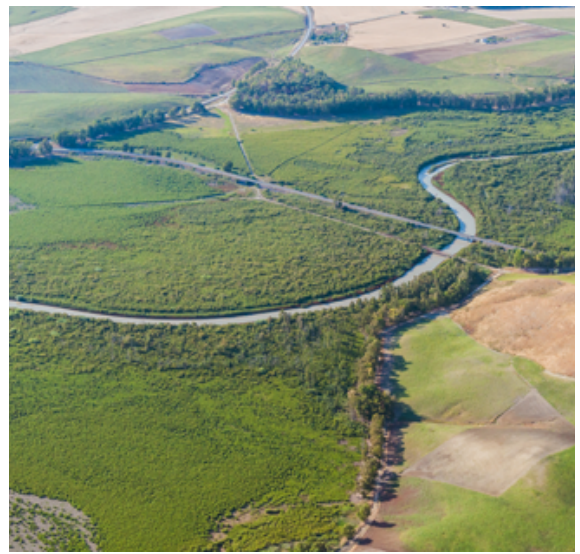

Río Guadalete a su paso por Bornos foto Manu García

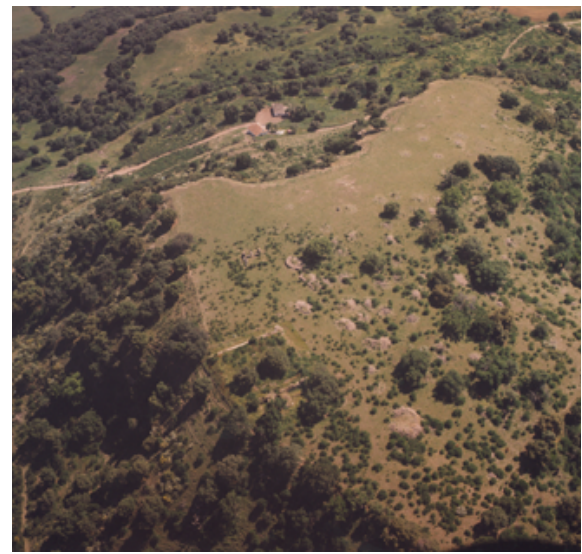

Yacimiento arqueológico de Iptuci (Prado del Rey) | foto Mancomunidad de Municipios de la Sierra de Cádiz 
MISA, 2008: 46). Ésta se dividió a su vez en tres subrutas temáticas e históricas. En primer lugar, el periodo prehistórico, incluido en la Ruta prehistórica, que estaría compuesta por el dolmen de Alberite en Villamartín, el dolmen del Charcón de El Gastor, los dólmenes de Tomillo en Alcalá del Valle y la necrópolis prehistórica de Fuente de Ramos de Puerto Serrano, conjuntos funerarios datables entre el IV y III milenio a.n.e., finales del Neolítico e inicios del Calcolítico. En segundo lugar, el periodo ibero-romano, encuadrado en la Ruta de las ciudades, con el yacimiento de sierra de Aznar en Arcos de la Frontera, Iptuci en Prado del Rey, Ocuri en Ubrique y Carissa Aurelia en Espera y el yacimiento del cerro de la Botinera en Algodonales. En tercer lugar, el periodo medieval, encuadrado en la Ruta de la frontera castellano-nazarí, en la que se incluyen la villa medieval de Zahara de la Sierra, la fortaleza de Olvera, la torre islámica y villa medieval de Setenil de las Bodegas, las murallas medievales de Torre-Alháquime, el barrio nazarí de Benaocaz y las calzadas medievales, aún transitables, de Villaluenga del Rosario y Grazalema (GUERRERO MISA; COBOS RODRÍGUEZ, 2002: 128).

Durante varios años se llevaron a cabo proyectos de diversa índole que iban configurando una visión histórica global de la Sierra de Cádiz, a través de la singularidad de cada uno de los yacimientos arqueológicos, bienes patrimoniales en general y centros de interpretación del patrimonio (históricos, etnográficos, culturales...), desarrollando un nuevo marco teórico en el que se presentaba la comarca en su conjunto como un auténtico "museo territorial" (GUERRERO MISA; COBOS RODRÍGUEZ, 2002: 122). Es en el año 2000 cuando el proyecto es denominado museo-territorio Sierra de Cádiz (GUERRERO MISA; COBOS RODRÍGUEZ, 2002: 122). Con este marco teórico se pretendía arropar conceptualmente, ya de una forma definitiva, todas las obras y acciones realizadas para la puesta en valor de los yaci-

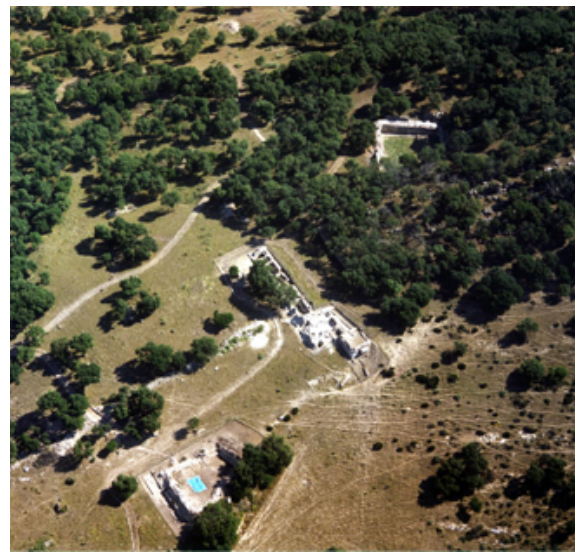

Yacimiento arqueológico de Sierra Aznar (Arcos de la Frontera) | foto Mancomunidad de Municipios de la Sierra de Cádiz

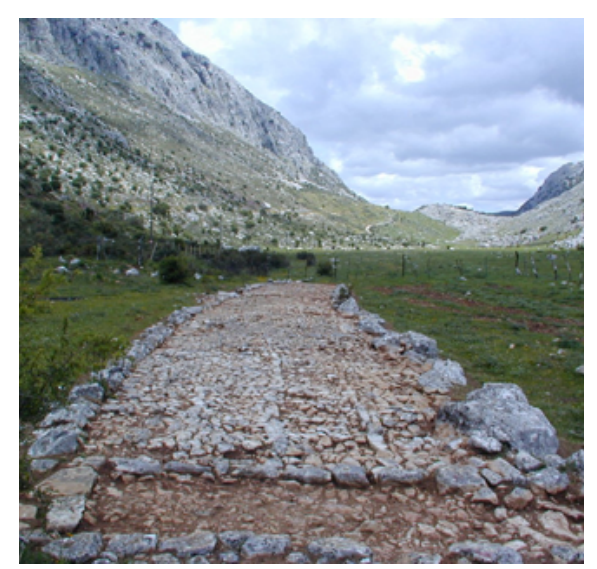

Calzada en la Manga de Villaluenga

foto Mancomunidad de Municipios de la Sierra de Cádiz

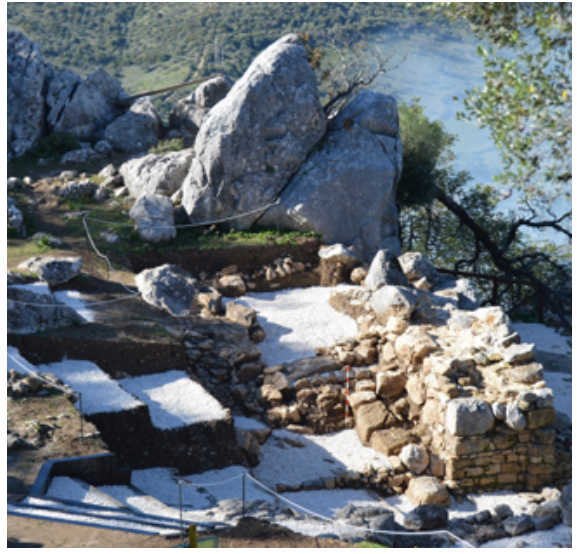

Puesta en valor del tramo de muralla ciclópea de Ocuri | foto Luis J. Guerrero 


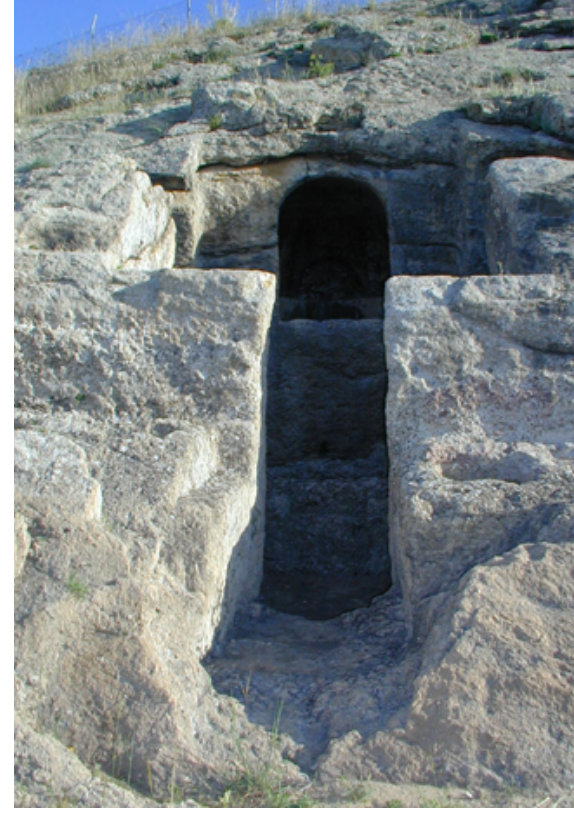

Hipogeo de Carissa Aurelia | foto Mancomunidad de Municipios de la Sierra de Cádiz mientos integrantes de la Ruta, mientras que, al mismo tiempo, se ofrecía tanto a la población local como a los visitantes, la posibilidad de disfrutar del patrimonio arqueológico y cultural de toda la sierra en una auténtica red integral turístico-cultural, convirtiéndola así en un auténtico museo al aire libre.

Este espacio musealizable comprende el patrimonio arqueológico y cultural de la Sierra de Cádiz en su globalidad, es decir, desde el entorno medioambiental y natural con sus connotaciones geográficas y bioclimáticas, hasta el conjunto básico formado por todos los restos arqueológicos e históricos que, de una $u$ otra forma, han llegado hasta nosotros.

Se apostaba, por consiguiente, por un proyecto de musealización integral del territorio, que entiende la Sierra de Cádiz como un gran "museo" al aire libre, en continua transformación, en el que debemos conservar, interpretar, mostrar y difundir nuestro rico patrimonio cultural (histórico, arqueológico, artístico, documental y etnológico) (GUERRERO MISA, 2008: 47).

El museo-territorio que se planteaba se fundamentaba en tres ámbitos: un territorio delimitado geográficamente, un patrimonio puesto en valor apoyado por las infraestructuras museísticas e interpretativas creadas (patrimonio material, inmaterial, natural y cultural) y una comunidad poblacional como agente protagonista y representante de la identidad patrimonial (GUERRERO MISA, 2008: 48).

En la actualidad la comarca de la Sierra de Cádiz presenta una red inacabada en torno al patrimonio cultural y, en particular, al patrimonio arqueológico, que constituye parcialmente ese museo-territorio referido con anterioridad. En los últimos años del proyecto se abrieron, o más bien sólo fueron inaugurados, varios centros de interpretación del patrimonio. Sin embargo, a la vez, yacimientos arqueológicos recuperados han vuelto a caer en el olvido de las administraciones. Este hecho contribuye a la percepción por parte de la ciudadanía de proyectos infructuosos, en los que ha faltado la fase de gestión y mantenimiento, la mayoría de las veces olvidada en la intervención del patrimonio. De todas formas, en la concepción teórica del proyecto se hablaba de un museo-territorio dinámico y activo. Quizás no sea éste el movimiento deseado, pero muestra la vitalidad de un recurso que se niega a desaparecer ya que numerosos visitantes recorren anualmente la comarca para conocer el territorio y sus bienes naturales y culturales más preciados y reconocidos.

Las debilidades y amenazas de hace quince o veinte años han ido modificándose a lo largo del tiempo, y las dificultades para la identificación de la diversidad arqueológica de la comarca, la escasa valoración y conciencia social de la importancia del patrimonio arqueológico, la insuficiencia de infraestructuras para su puesta en valor, o la ausencia de equipos estables de profesionales que lo gestionen, han sido superadas y sustituidas. En cam- 
bio, aparecen otros factores como la falta de planteamientos globales sobre la gestión e intervención en el patrimonio arqueológico, las escasas acciones de difusión o la falta de una política educativa patrimonial y, por supuesto, la crisis económica.

Para paliar estas fragilidades el patrimonio arqueológico de la Sierra de Cádiz posee una serie de potencialidades que ofrecen sus recursos, como son: la enorme variedad y riqueza de los restos arqueológicos; un bloque de profesionales del patrimonio cultural y arqueológico formados y disponibles; la existencia de un amplio marco jurídico en el campo del patrimonio; la posibilidad de cooperación con universidades y otros centros altamente cualificados; el interés creciente de la sociedad por el patrimonio cultural, en general, y arqueológico; el aumento del turismo cultural dentro de Andalucía y de la Sierra de Cádiz con la demanda de productos y servicios; la creciente participación de otras administraciones en la financiación del patrimonio arqueológico; y su más que posible inclusión en planes de desarrollo comarcales y europeos ${ }^{4}$.

\section{HACIA NUEVOS MODELOS DE GESTIÓN}

Es posible, por tanto, recuperar estas iniciativas patrimoniales que, junto a nuevas perspectivas, hagan posible los retos que nos propusimos hace ya más de quince años. Se trataría de articular las políticas de investigación, conservación y difusión que corresponden a la administración cultural, con otras políticas de desarrollo local o rural que se basan en la complementariedad de los recursos, tanto económicos como patrimoniales.

Es necesario un replanteamiento de lo que hoy, ya en la segunda década del siglo XXI, representa el patrimonio arqueológico y cuál es su función en nuestra sociedad, en relación con la población que lo disfruta y el territorio donde se localiza. Preguntarnos si siguen siendo útiles los planteamientos de los años noventa, cuando se inicia la democratización de la cultura en España, y si han respondido a las expectativas que se crearon en su momento sobre el patrimonio desde las perspectivas sociales y económicas.

En suma, debemos proponer estrategias que posibiliten proyectos de futuro en esos espacios patrimoniales. Para ello es imprescindible promover mecanismos que creen sinergias entre los agentes que intervienen en el patrimonio, a saber: administraciones públicas (ayuntamientos, Diputación de Cádiz y Junta de Andalucía), universidades, asociaciones de defensa del patrimonio, profesionales, sector privado, y ciudadanos en general, para que coordinen planes estratégicos de actuación ${ }^{5}$.
4

Programa de Desarrollo Rural de la Consejería de Agricultura, Pesca y Desarrollo Rural de la Junta de Andalucía y la Unión Europea. Programas con contenidos patrimoniales y vinculación estratégica al desarrollo territorial, ligado estrechamente a la valorización del patrimonio arqueológico.

5

Sería muy interesante la creación de una Mesa del Patrimonio de la Sierra de Cádiz, para la búsqueda de un modelo territorial basado en la ordenación de los bienes culturales y en su gestión. 


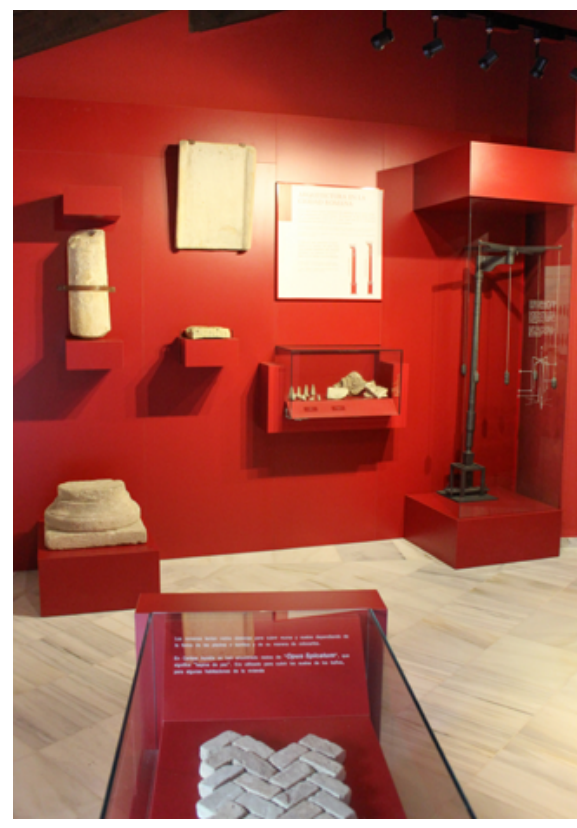

Museo Arqueológico de Espera | Pepa Lozano
Ahora bien, si existen ya modelos de gestión de los espacios culturales promovidos por la Consejería de Cultura de la Junta de Andalucía, caso de la Red de Espacios Culturales de Andalucía (RECA), sería recomendable el acercamiento de los entes municipales a los órganos competentes para la redacción de convenios bilaterales que posibiliten la inclusión en esta red del patrimonio arqueológico de la Sierra de Cádiz. Estos enclaves tienes entre sus prioridades contar con un Plan Director como instrumento de planificación y gestión a corto y medio plazo.

Igualmente puede entenderse, en virtud de la Ley 14/2007de 26 de noviembre de Patrimonio Histórico de Andalucía, que la Sierra de Cádiz pueda considerarse una de las nuevas tipologías establecidas por esta normativa en cuanto a la clasificación de bienes inmuebles. Nos referimos a las zonas patrimoniales definidas como "aquellos territorios o espacios que constituyen un conjunto patrimonial, diverso y complementario, integrado por bienes diacrónicos representativos de la evolución humana, que poseen un valor de uso y disfrute para la colectividad y, en su caso, valores paisajísticos y ambientales" (LEY 14/2007). Y para la ordenación de estos espacios, la ley misma crea la figura de parques culturales que requerirán "la constitución de un órgano de gestión en el que participen las administraciones y sectores implicados".

Es por ello que es posible recuperar la idea primigenia del museo-territorio, donde se pertenezca a un sistema integrado, unitario y normalizado que garantice su continuidad y la posibilidad de inversiones que hagan avanzar en la puesta en valor del patrimonio arqueológico. Un espacio donde cultura y naturaleza van, conjuntamente, en busca de un desarrollo sostenible, que no es otra cosa que el equilibrio entre la conservación y la puesta en valor a largo plazo de sus recursos patrimoniales. Es, en definitiva, patrimonio territorial como "parte del conjunto de recursos culturales y naturales heredados en un espacio geográfico dado, que tienen un elevado grado de aceptación y reconocimiento social" (ORTEGA, 1998: 34).

Así pues, el patrimonio arqueológico no debe desvincularse del territorio cultural de la Sierra de Cádiz, como una apuesta aislada, sino como perteneciente a una oferta más amplia y diversificada. Del mismo modo, debe fijar sus cimientos en la ciudadanía como pilar fundamental para su desarrollo. Se trataría de crear nuevos discursos con mecanismos diferentes que potenciaran la relación entre expertos y comunidad local, donde sería fundamental incorporar a personas y colectivos sociales, fuera del ambiente universitario y técnico, para una mayor implicación y participación ciudadana. Esta complicidad entre comunidad local y expertos deberá buscar fórmulas para facilitar la recuperación de un proyecto de museo-territorio de la Sierra de Cádiz donde se primen los valores educativos y el turismo cultural sostenible, siguiendo siempre buenas prácticas de uso del patrimonio. 


\section{BIBLIOGRAFÍA}

- AA.VV. (1995) Esquema Territorial de la Cuenca del Guadalete. Sevilla: Consejería de Obras Públicas y Transporte de la Junta de Andalucía, 1995. 124 p.

- CARAVACA BARROSO I.; FERNÁNDEZ SALINAS V. (2005) Patrimonio y Desarrollo Territorial. Actas de Jornadas de Patrimonio y Territorio. Sevilla: Consejería de Cultura de la Junta de Andalucía, 2005, pp. 5-18

- CATÁlogo General del Patrimonio Histórico Andaluz [en línea]. Consejería de Cultura, Junta de Andalucía, 2013 $<$ http://www.juntadeandalucia.es/cultura/web/areas/bbcc/ catalogo> [Consulta: 24/01/2016]

- COBOS RODRíGUEZ, L. M. (2003) Zahara. Memoria recuperada del Patrimonio Arqueológico. Zahara de la Sierra: Ayuntamiento de Zahara de la Sierra, 2003, 86 p.

- DECRETO de 22 de abril de 1949 sobre la Protección de Castillos Españoles, expedido por el Ministerio de Educación Nacional. Boletín Oficial del Estado, del 5 de mayo de 1949

- DECRETO 316/1984, de 18 de diciembre, de declaración del Parque Natural de la Sierra de Grazalema. Boletín Oficial de la Junta de Andalucía, n. ${ }^{\circ}$ 13, 12 de febrero 1985

- GUERRERO MISA, L. J. (2008) Desarrollo y consolidación de La Ruta Arqueológica de los Pueblos Blancos de la Sierra de Cádiz: la musealización de un territorio. En Actas de las VIII Jornadas Andaluzas de Difusión del Patrimonio Histórico (Almería, 22-24 de febrero de 2005). Sevilla: Consejería de Cultura, 2008, pp. 43-57

- GUERRERO MISA L. J.; COBOS RODRÍGUEZ L. M. (2002) La Ruta Arqueológica de los Pueblos Blancos de la Sierra de Cádiz: Una apuesta por el desarrollo económico y social basada en el Patrimonio. En SÁNCHEZ DE LAS HERAS, C. (coord.) Actas VI Jornadas de Difusión del Patrimonio. Sevilla: Consejería de Cultura de la Junta de Andalucía, 2002, pp. 121-138

- LEY 2/1989 de 18 de julio, por la que se aprueba el inventario de Espacios Naturales Protegidos de Andalucía y se establecen medidas adicionales para su protección. Aprobada por el Pleno del Parlamento los días 27 y 28 de junio de 1989. Boletín Oficial de la Junta de Andalucía, n. ${ }^{\circ}$ 60, de 27 de julio de 1989

- LEY $14 / 2007$ de 26 de noviembre de Patrimonio Histórico de Andalucía, en sesión celebrada los días 14 y 15 de noviembre de 2007. Boletín Oficial de la Junta de Andalucía, n. ${ }^{\circ}$ 248, de 19 de diciembre de 2007 (arts. 26.8 y 81)

- ORTEGA, J. (1998) El patrimonio territorial: el territorio como recurso territorial y económico. Revista Ciudades, n. ${ }^{\circ}$ 4, Territorio y Patrimonio. Valladolid: Instituto Universitario de Urbanística de la Universidad de Valladolid, 1998, pp. 33-48 


\section{El patrimonio inmaterial en la Sierra de Cádiz: aproximación a los rituales festivos}

Rosa Satué López | antropóloga

URL de la contribución <www.iaph.es/revistaph/index.php/revistaph/article/view/3732>

\section{RESUMEN}

Es la comarca situada más al norte de la provincia. Aunque su economía sigue siendo esencialmente agraria, el sector turístico tiene un peso cada vez mayor en la economía y se nutre de la buena conservación del entorno natural y la belleza de sus pueblos y, cada vez más, de la existencia de un patrimonio cultural vivo, variado y diferenciado de otras zonas.

En este artículo abordamos los rituales festivos, una parte muy significativa del patrimonio inmaterial de la Sierra de Cádiz. Se trata, en su mayoría, de rituales festivo-ceremoniales religiosos, normalmente en torno a la imagen de una virgen o un santo, como símbolos de identificación colectiva. Pero también encontramos celebraciones profanas, carnavales y ferias, así como fiestas de nueva creación. Los rituales festivos más generalizados son la Semana Santa, las romerías, el corpus, las ferias y las fiestas patronales.

\section{Palabras clave}

Andalucía | Cádiz (Provincia) | Patrimonio inmaterial | Rituales festivos | Romerías | Sierra de Cádiz | 


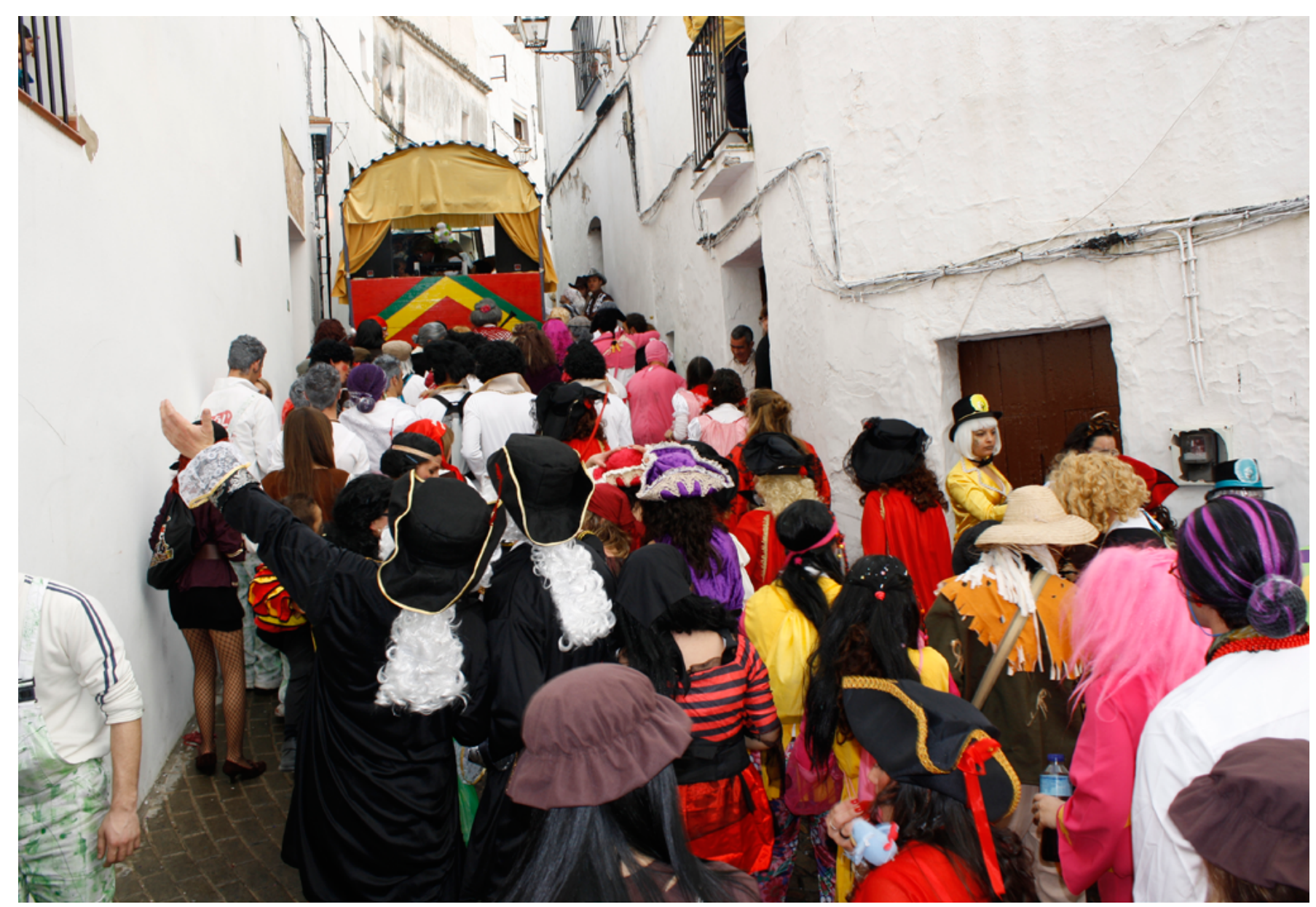

Cabalgata de Carnaval de Arcos de la Frontera | foto Fondo Gráfico IAPH (Rosa Satué López), para todas las imágenes del artículo 
La Sierra de Cádiz es la comarca situada más al norte de la provincia. Sus límites terminan donde comienzan las comarcas de la Campiña de Jerez, la Serranía de Ronda, el Bajo Guadalquivir y la Sierra Sur de Sevilla. Posee una enorme variedad de valores paisajísticos y ambientales debido a su geomorfología, caracterizada por la transición progresiva desde los terrenos de campiña de la zona occidental (sierra baja) a los paisajes más propiamente de montaña de la Sierra de Grazalema, en la parte más oriental (sierra alta). Tiene una superficie de $1.998 \mathrm{~km} 2$ y la componen los siguientes municipios: Alcalá del Valle, Algar, Algodonales, Arcos de la Frontera, Benaocaz, Bornos, El Bosque, Espera, El Gastor, Grazalema, Olvera, Prado del Rey, Puerto Serrano, Setenil de las Bodegas, Torre Alháquime, Ubrique, Villaluenga del Rosario y Villamartín.

La economía de esta zona sigue siendo esencialmente agraria, salvo en algunos municipios como Ubrique. En la sierra baja existe un equilibrio entre las tierras dedicadas a cultivos, cereal y olivar predominantemente, y los usos ganaderos y forestales del espacio. Mientras que en la sierra alta el porcentaje de tierras cultivadas es sólo testimonial y es el sector ganadero, con la explotación de razas autóctonas caprinas (payoya), ovinas (merina grazalemeña) y bovinas (retinta y pajuna), el pilar básico de la economía.

En cuanto al sector secundario, Ubrique concentra la mayor parte de las industrias de su área y está especializada en el tratamiento de la piel y la marroquinería, con las consiguientes empresas auxiliares. Vinculados al sector de la piel están Prado del Rey y, en menor medida, Benaocaz y El Bosque. Tanto Prado del Rey como Benamahoma conservan empresas dedicadas tradicionalmente a la fabricación de muebles artesanales y en Grazalema pervive una fábrica de mantas artesanales, reducto del importante complejo industrial que se desarrolló en este municipio en el pasado. Con todo, la

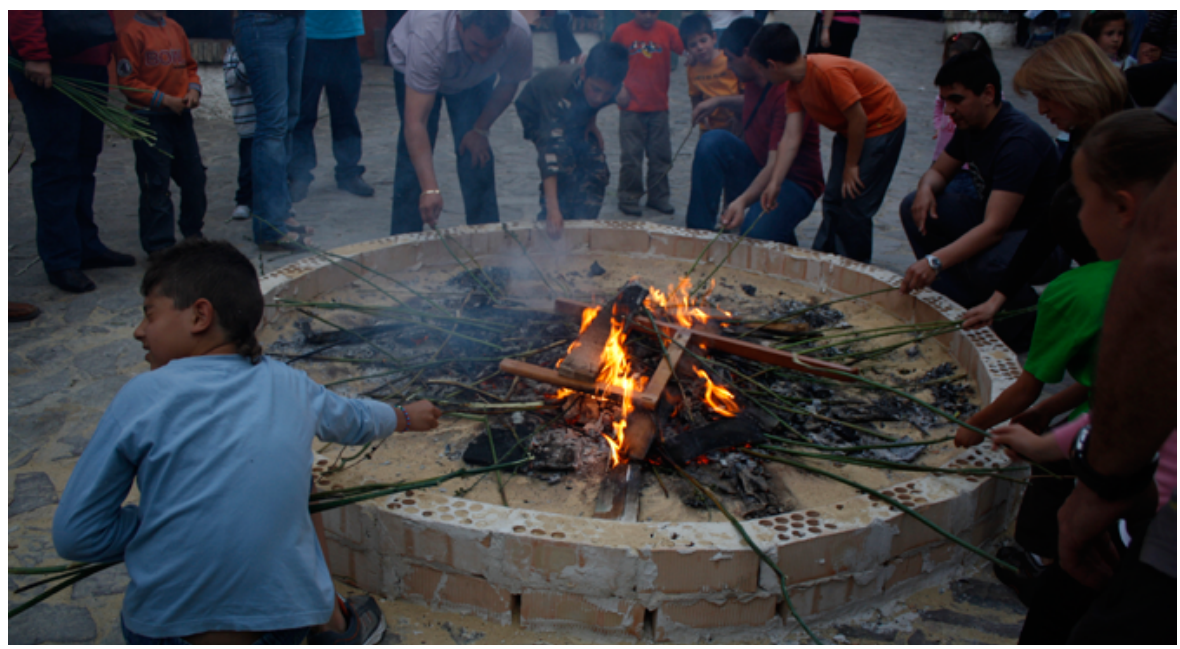


actividad productiva con mayor presencia en estos municipios gaditanos es la industria agroalimentaria, especialmente la relacionada con productos cárnicos (embutidos y chacinas) y lácteos (quesos) procedentes de la cabaña autóctona, además de aceite de oliva, miel, vino y mermelada, entre otros.

El sector turístico tiene un peso creciente en la economía de la comarca. La declaración de Reserva de la Biosfera por la UNESCO de la Sierra de Grazalema en 1977 y, posteriormente, la creación del Parque Natural en 1984, significó un impulso para el desarrollo turístico de las poblaciones que integran este territorio. La oferta turística se amplió más tarde con la promoción de la ruta de los Pueblos Blancos, en la que están presentes todos los pueblos de la Sierra de Cádiz. La demanda turística se nutre de la buena conservación del entorno natural y la belleza de sus pueblos y, cada vez más, de la existencia de un patrimonio cultural vivo, variado y diferenciado de otras zonas.

El patrimonio inmaterial de la Sierra de Cádiz es un ejemplo más de la riqueza y diversidad de la cultura andaluza. No es posible abundar en su conjunto y, por ello, nos detendremos en una parte significativa del mismo: los rituales festivos. La mayor parte de las celebraciones que encontramos en la sierra gaditana corresponde, como es común a todo el territorio andaluz, a rituales festivo-ceremoniales religiosos, normalmente en torno a la imagen de una virgen o un santo, referentes de gran importancia en Andalucía como símbolos de identificación colectiva. Pero, junto a ellos, también es posible encontrar celebraciones profanas, carnavales y ferias, así como fiestas de nueva creación.

Los rituales y fiestas están insertos en procesos históricos concretos y, por tanto, sujetos a evoluciones y modificaciones derivadas de su continua readaptación a los nuevos contextos. En concreto, los fuertes cambios que se introdujeron en el modelo productivo del país a partir de finales de los años

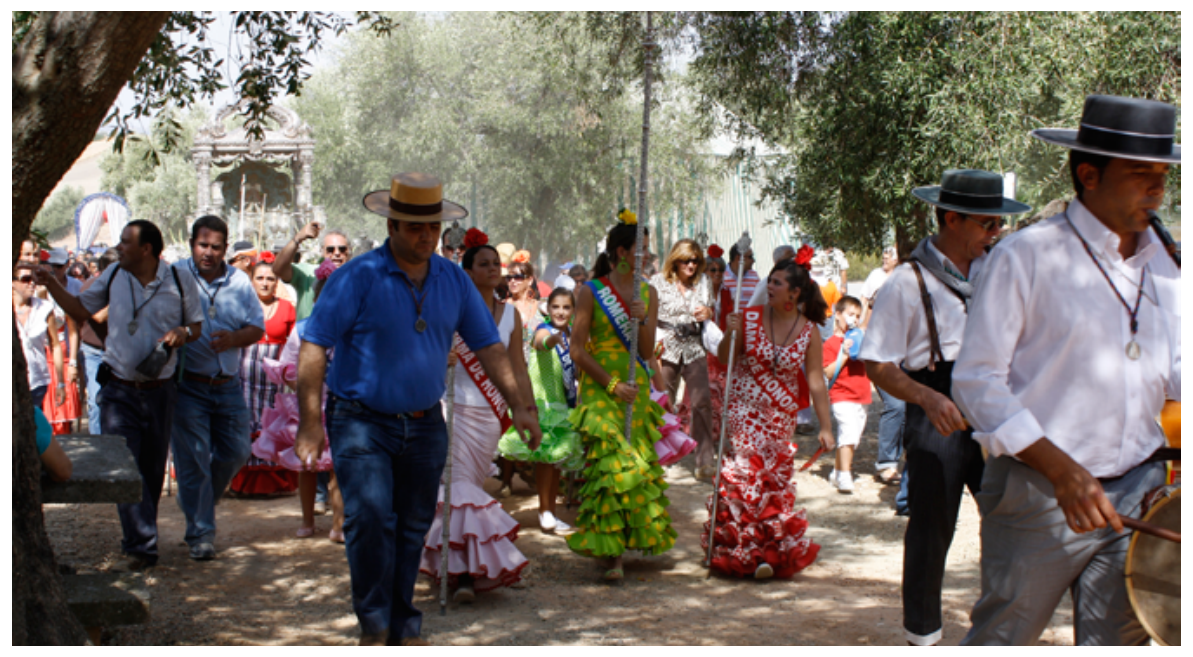

Romería de la Virgen de las Montañas de Villamartín 

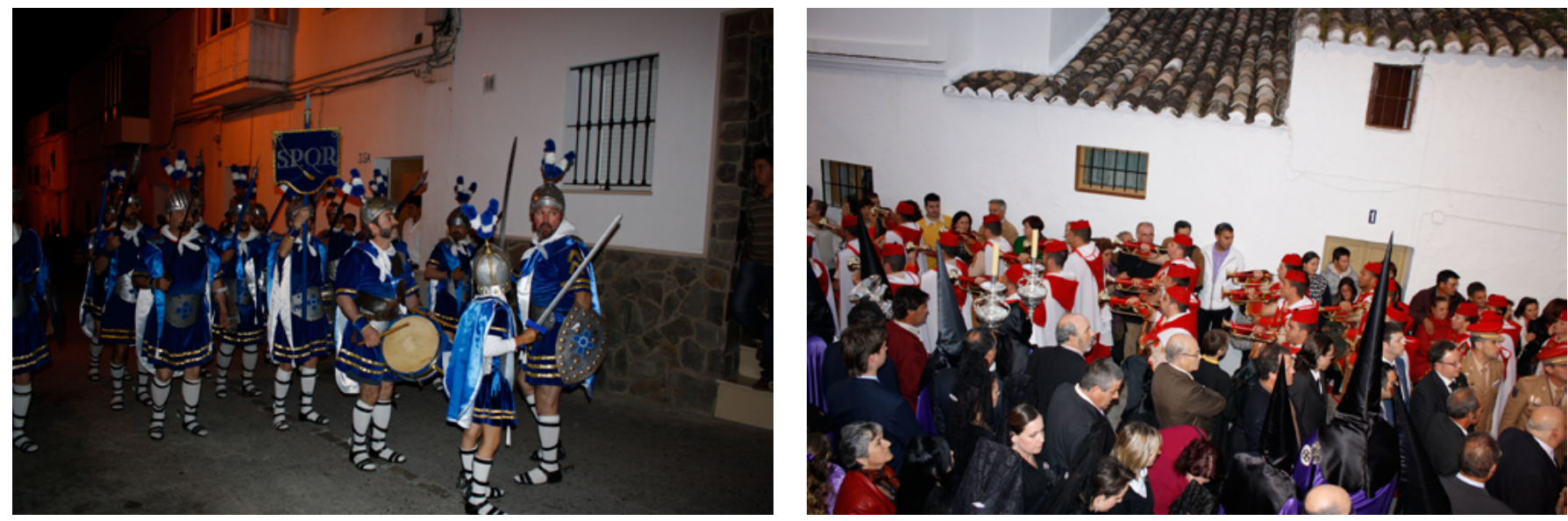

Armaos de San Antonio de Arcos de la Frontera (arriba)

Procesión de los Negros de Setenil de las Bodegas (derecha)

cincuenta del pasado siglo, con la implantación del Plan de Estabilización, y el desarrollismo económico afectaron de una manera determinante al mundo rural y, especialmente, a los pueblos de las sierras andaluzas, que experimentaron un rápido proceso de despoblamiento. En la Sierra de Cádiz fue numerosa la emigración a Europa, y dentro de España al norte y a las zonas costeras, lo que dio lugar a una desarticulación de los grupos sociales y de las bases económicas de los municipios, que se proyectó en los ciclos festivos. Los rituales y fiestas perdieron, por lo general, su funcionalidad como marcadores de los ritmos de trabajo y descanso de acuerdo con los ciclos agrarios y pasaron a estar regidos por pautas urbanas e industriales. Dejaron de ser periodos de impasse y regreso al pueblo de las personas que vivían y trabajaban próximas pero dispersas en los campos, para convertirse en espacios de reencuentro entre los emigrantes y los que permanecieron en la sierra, pero ya solo en torno a unas celebraciones concretas, las que se adaptaban a las vacaciones de la población desplazada, y no a todas. Con ello, los ciclos festivos se simplificaron y desaparecieron algunas celebraciones. En este contexto, los tiempos de la fiesta empezaron a experimentar modificaciones. Algunos rituales centrales, como las procesiones, se trasladaron a los fines de semana en numerosas localidades y, aunque en otras continuó respetándose el día de la advocación, los festejos se alargaron hasta el fin de semana más próximo para ampliar las posibilidades de participación de quienes no residían en la localidad. El cambio en las formas no ha supuesto una pérdida de su dimensión integradora e incluso ha contribuido a reforzarla con el añadido de nuevos grupos sociales. Son numerosas las fiestas y rituales que se han reproducido a lo largo del tiempo como expresiones culturales vivas, cambiantes, con mayor complejidad o simplificadas según el caso, pero que mantienen su funcionalidad como referentes de un "nosotros" colectivo, "el pueblo" concebido como comunidad de origen con unos valores sociales compartidos. 

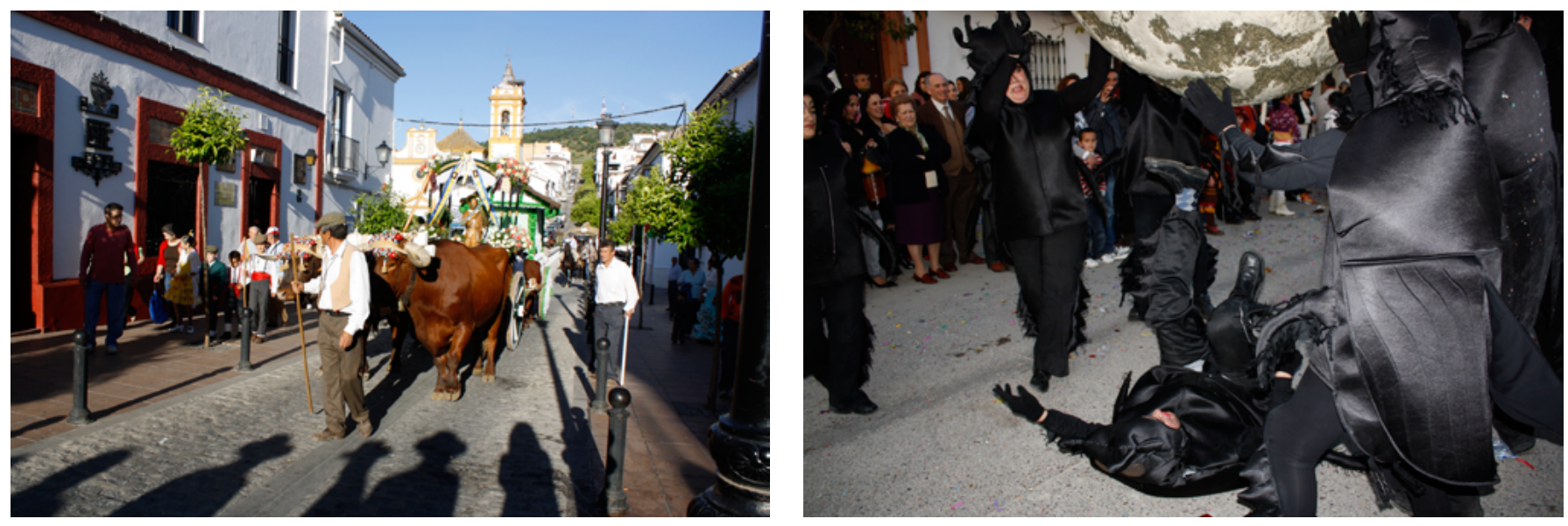

Escarabajos peloteros en el Carnaval de Puerto Serrano (izquierda)

Los rituales festivos más generalizados, por tener lugar en casi todos los municipios de la comarca, son la Semana Santa, las romerías, el Corpus, las ferias y las fiestas patronales, si bien presentan rasgos y grados de complejidad diferentes.

La Semana Santa tiene mucha importancia en la comarca y, salvo en El Bosque, en todos los municipios existen cofradías. Además, en Arcos de la Frontera, Setenil de las Bodegas, Espera, Olvera y Alcalá del Valle han sido declaradas de Interés Turístico Nacional. En todas ellas destacan elementos formales que otorgan un estilo propio a las procesiones o a la festividad y las dotan de una singularidad que marca la diferencia como colectivos, cuando se trata de grupos sociales concretos, o como comunidad local. Ejemplo de ello son Los Negros y Los Blancos de Setenil de las Bodegas, tradicionales "mitades" que se reproducen, con sus particularidades, en distintos municipios andaluces. Se trata de una peculiar forma de rivalidad ritual de carácter dual, a partir de la adscripción de la sociedad local a una u otra hermandad. También, el Auto sacramental de La Carrerita de San Juan en Alcalá del Valle o los paseos de los armaos de Arcos de la Frontera.

El proceso de asimilación de elementos de la Semana Santa sevillana, sobre todo, pero también malagueña, que se había generalizado en toda Andalucía en las pasadas décadas, está revirtiendo en muchas de estas localidades serranas y, como consecuencia, se están recuperando las formas más tradicionales de portar los pasos, así como las ropas y enseres que habían ido desapareciendo del espacio ritual. En este nuevo contexto, la singularidad y la vuelta a la tradición son igualmente elementos que están reforzando el sello diferenciador de unas localidades frente a las otras.

La fiesta del Corpus, que en muchas localidades ha perdido parte de su significación para convertirse exclusivamente en un acto litúrgico, mantiene su
Romería de San Isidro Labrador de Prado del Rey (arriba) 


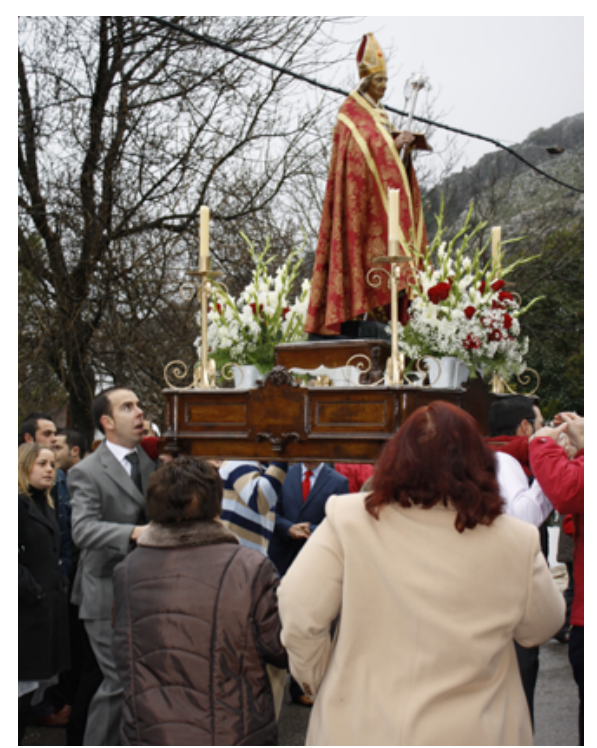

Procesión de San Blas de Benaocaz (arriba)

Procesión de la Virgen del Carmen de Grazalema (centro)

Calle ornamentada para el Corpus de El Gastor (derecha)
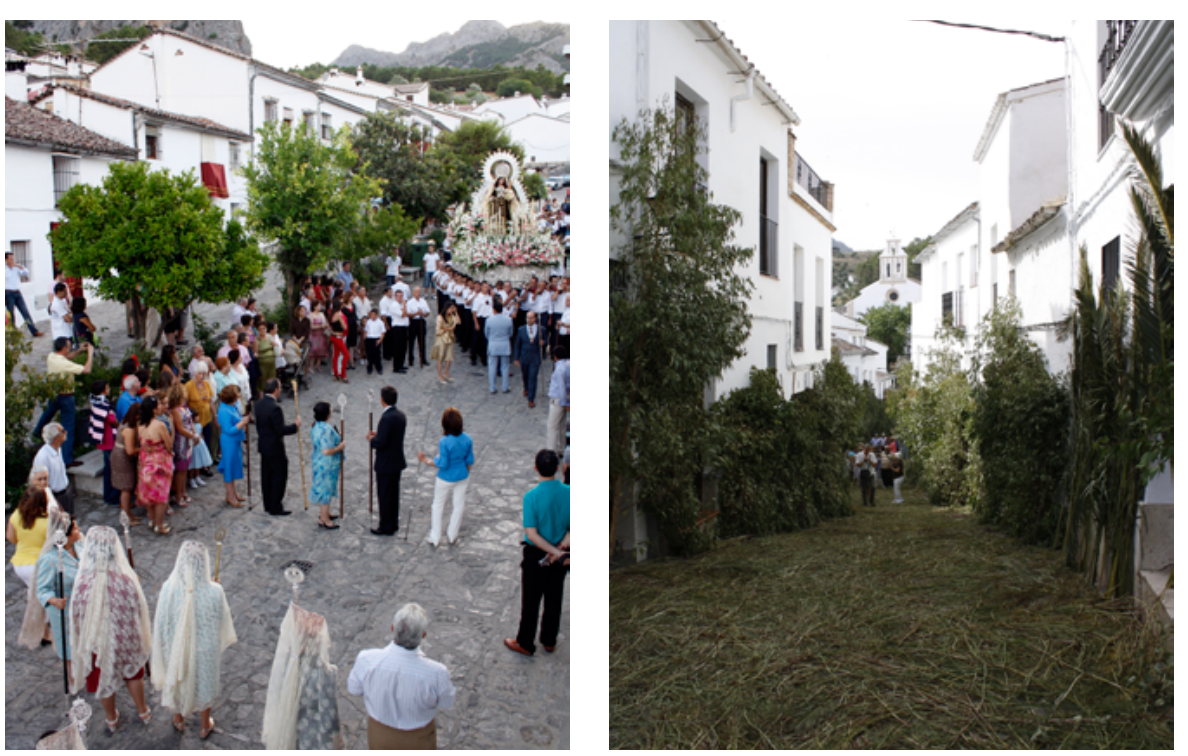

relevancia en Zahara de la Sierra y El Gastor. En ambas localidades destaca el ornamento con ramas y juncias que, por un día, convierte a estos pueblos blancos en bosques frondosos de especial colorido y vistosidad, acogiendo a un gran número de visitantes.

Las ferias suelen coincidir con las fiestas patronales, salvo en algunas poblaciones como Villamartín, Bornos o Espera. Muchas de ellas tienen su origen en antiguas ferias en torno a la compra-venta de ganado. Este tipo de encuentros fue perdiendo su función principal como consecuencia de los cambios socioeconómicos experimentados en la comarca a partir de los años sesenta, aunque se conservan en algunas localidades. Un ejemplo significativo es la feria de San Mateo en Villamartín, declarada de Interés Turístico Nacional.

Los festejos patronales son los que tienen mayor importancia en los pueblos más pequeños de la sierra. Como ya se ha mencionado, en ellos la celebración del día del patrón o patrona y la feria de la localidad suelen coincidir. La mayoría de estas celebraciones responden a un esquema similar. El ritual central se compone de una misa y la procesión en honor a la imagen protectora de la localidad y, junto a ello, hay una parte lúdica que incluye verbenas diurnas y nocturnas en la plaza principal, actividades culturales y/o deportivas y un final de fiesta con fuegos artificiales. Aunque los carnavales, el Corpus o la Semana Santa tienen una fuerte dimensión identitaria en varios municipios de la sierra, como Bornos (carnaval), El Gastor o Zahara de la Sierra (el Corpus) o Setenil de las Bodegas (la Semana Santa), es en las fiestas patronales donde se refuerzan, en mayor medida, los sentimientos de pertenencia a una comunidad simbólica representada por la localidad de origen e identificada con la imagen patronal. Son éstas las fechas en las que 

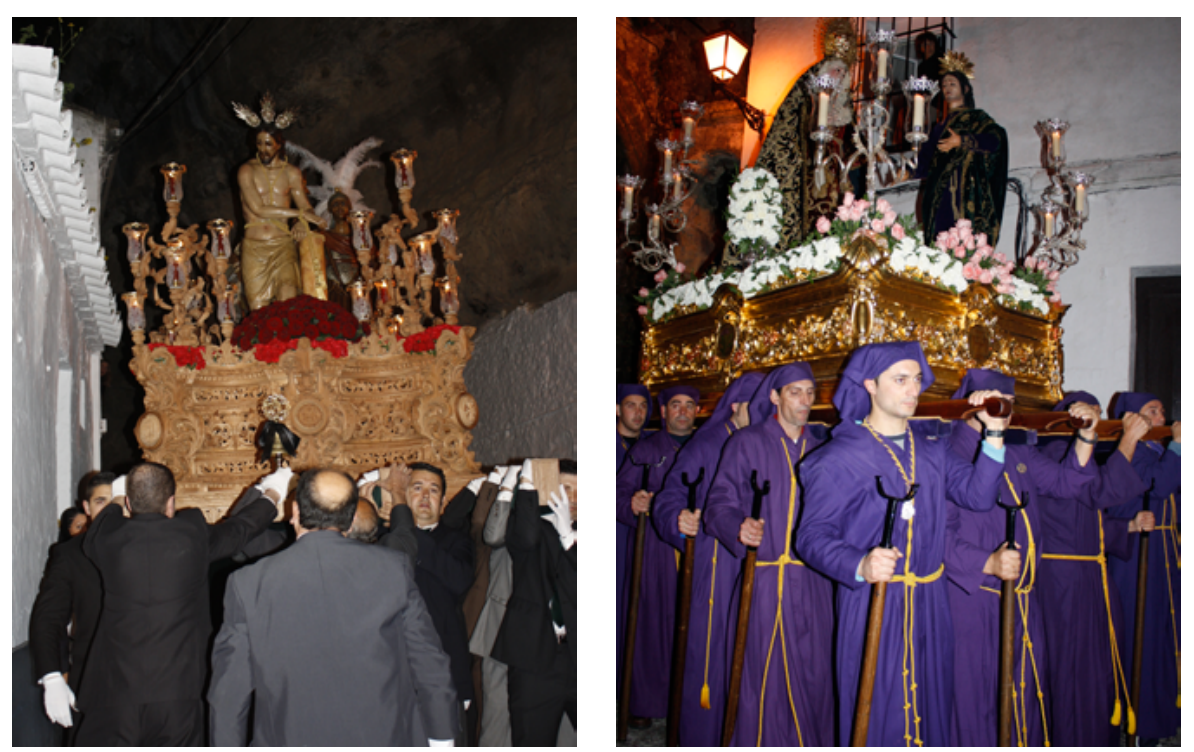

la población emigrante regresa a sus pueblos, coincidiendo con las vacaciones, al igual que lo hacen quienes residen en otras localidades próximas y mantienen un contacto más continuado con su lugar de origen. La participación en las fiestas, y en concreto en la procesión, manifiesta el deseo de pertenencia que se conserva en la distancia. La presencia, además, adquiere especial significación porque, en muchos casos, proyecta en el espacio ritual una fidelidad a la comunidad que se ha manifestado a través de los años. Entre otras cosas, a través de los apoyos económicos para compra de enseres, arreglo de imágenes y otras mejoras de patrimonio mueble e inmueble.

Las romerías responden a distintos esquemas. Unas consisten en traslados de las imágenes patronales a las ermitas; es el caso de la romería de la Malena de Puerto Serrano, o a las afueras del núcleo urbano, como la romería de San Antonio de Padua de El Bosque. Otras son peregrinaciones del pueblo a la ermita donde se encuentra la imagen, como ocurre en la romería de las Montañas de Villamartín o el Lunes de Quasimodo de Olvera. En ambos casos, con una clara función simbólica de apropiación del espacio ritual. Igualmente, por su carácter agrario, siguen siendo significativas en muchas localidades serranas las romerías de San Isidro Labrador, en especial, en Prado del Rey, Ubrique, Setenil de las Bodegas, Algodonales, Alcalá del Valle y Grazalema. En todas estas romerías, en mayor o menor medida, encontramos elementos propios de las de la baja Andalucía: Ios trajes rocieros o de flamenca, los cantes por sevillanas, la incorporación de un camino para hacer en comunidad o la presencia de carrozas, carretas y caballos.

Las Cruces de Mayo, muy generalizadas antes en todo el territorio andaluz, se celebran en la actualidad en Arcos de la Frontera, donde se han recu-

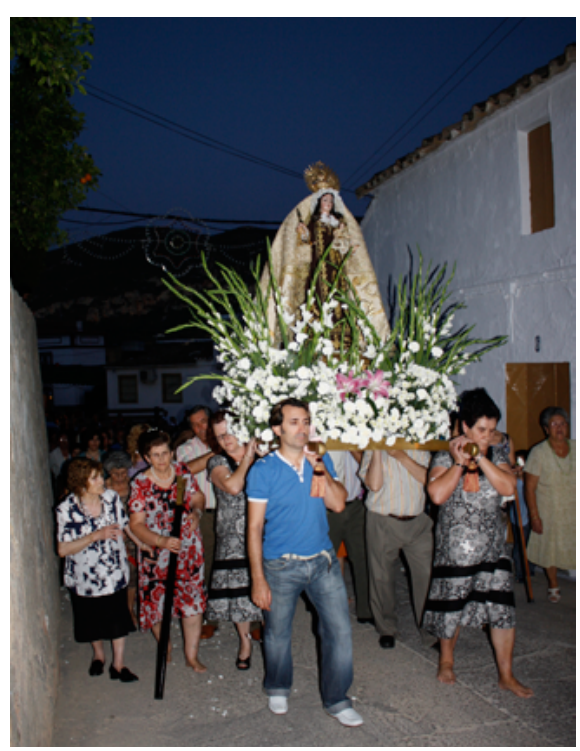

Procesión de la Virgen del Carmen de La Muela de Algodonales (arriba)

Procesión del Nazareno de Arcos de la Frontera (centro)

Procesión de los Blancos de Setenil de las Bodegas (izquierda) 


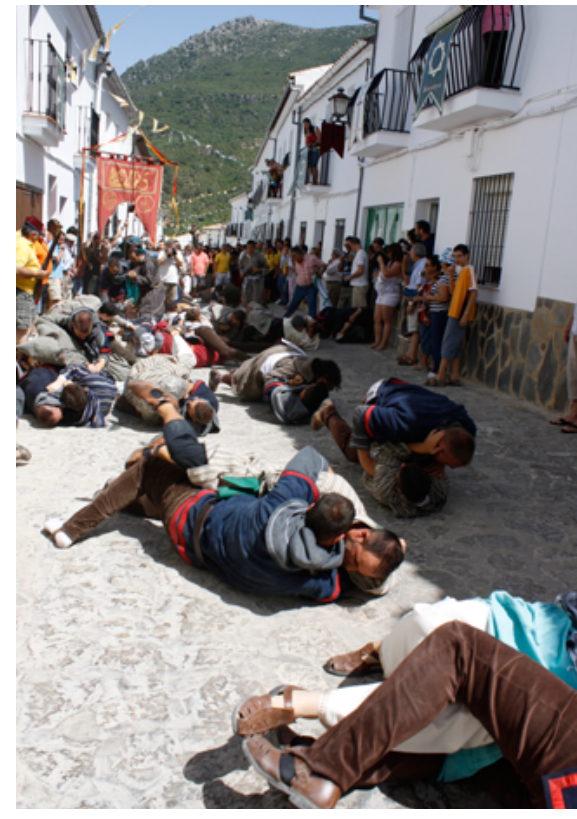

Moros y Cristianos (Las Luchas) de Benamahoma

perado a iniciativa del Ayuntamiento, con la participación de asociaciones y vecinos, y en Ubrique. El día de los Gamones es una de las fiestas más representativas de Ubrique. Este día se engalanan las calles, plazas y cruces y, por la noche, se encienden cientos de hogueras en las que se hacen crujir los gamones, unas varas recogidas previamente en los campos cercanos. Los carnavales, prohibidos durante la dictadura franquista como en el resto de España, se recuperaron en la mayoría de las poblaciones de la Sierra de Cádiz, fundamentalmente, a lo largo de los años ochenta. En la actualidad se celebran carnavales en casi todos ellas aunque con distinta relevancia. Destacan los carnavales de Bornos, Arcos de la Frontera, Ubrique, Puerto Serrano y Setenil de las Bodegas. Bornos conserva rasgos del carnaval rural, pero, en general, se han asimilado elementos carnavalescos del modelo gaditano y suelen ser habituales las actuaciones de chirigotas de Cádiz. Un caso singular es el de Puerto Serrano, donde se ha creado un modelo de agrupación carnavalesca diferente a las tradicionales gaditanas, en la que sus integrantes no cantan coplas y los elementos más relevantes, que componen una original puesta en escena, son el "tipo", la coreografía y los "armatostes" (objetos muy diversos y de distintos tamaños que complementan la escenografía).

Otras celebraciones más minoritarias responden al desarrollo de un modelo propio o que incluyen algún elemento singular dentro de la comarca, como rasgo identificador a nivel local. Es el caso de los toros enmaromaos de la fiesta de San Roque de Villaluenga del Rosario, las Fiestas Mayores de Benaocaz y de las Fiestas del Carmen de Grazalema. El toro ensogado por los cuernos recorre las calles del municipio mientras los corredores, sobre todo hombres pero en los últimos años también mujeres, citan, huyen, y hacen recortes al astado. El día de San Blas en Benaocaz el santo recorre el pueblo, sin itinerario establecido, bailando junto con los benaocaceños al ritmo enérgico de una charanga. $Y$ en Benamahoma tiene lugar la única fiesta de Moros y Cristianos de la comarca, en la que sobresalen los retos verbales, diálogos desafiantes $y$, en su mayor parte, improvisados, que intercambian los capitanes moro y cristiano y "las luchas" rituales en las que se enzarzan ellos y sus seguidores, rodando por el suelo emparejados en un abrazo. Son elementos rituales, ambos, que no están presentes en otras celebraciones de moros y cristianos.

En los últimos años se está impulsando la recuperación de rituales abandonados, se han potenciado los festejos patronales y, paralelamente, se están creando nuevas fiestas. Esto responde a una manera de entender los nuevos discursos sobre el patrimonio cultural, de resignificar la recuperación de lo tradicional, "de lo propio", como recurso dentro de una política local y comarcal destinada al fomento del turismo rural como un eje fundamental del desarrollo económico. Pero, igualmente, responde a la necesidad de frenar el despoblamiento de estos pueblos, de crear o recuperar momentos en los 
que se recrea la comunidad imaginada, de responder a las demandas de los diferentes colectivos sociales y de las diferentes sensibilidades que habitan los municipios. Por ello, es significativo que en las fiestas de mayor centralidad, sobre todo en las fiestas patronales, se tienda cada vez más a dedicar momentos de protagonismo específico para los distintos grupos de edad o agrupaciones de diverso tipo, que se concretan en comidas especiales, actividades y actuaciones. La necesidad de reforzar el sentido de comunidad, al mismo tiempo que las demandas de unas sociedades locales crecientemente heterogéneas, así como de rentabilizar, social y económicamente, las fiestas está conduciendo a una mayor complejidad de las mismas.

\section{BIBLIOGRAFÍA}

- Agudo TORRICO, J. (2001) Romerías, Ferias y Fiestas. En Conocer Andalucía: Gran Enciclopedia Andaluza del Siglo XXI. Vol. 6. Santander: Ediciones Tartessos, 2001, pp. 257-303 
$\mathrm{PH} \mathbf{8 9}$

\title{
Museo Arqueológico de Espera (MAE)
}

\author{
Pepa Lozano Ramírez | directora del MAE \\ URL de la contribución <www.iaph.es/revistaph/index.php/revistaph/article/view/3728>
}

\section{RESUMEN}

Espera es un municipio de 4.000 habitantes, ubicado al norte de la provincia de Cádiz, con una gran riqueza a nivel arqueológico. Sus dos yacimientos principales son Carissa Aurelia, declarado BIC en 2003 (Decreto 339/2003, de 2 de diciembre), y Esperilla, identificada por algunos autores como la ciudad de Cappa; su secuencia poblacional empieza en el Neolítico y continúa prácticamente de manera ininterrumpida hasta época medieval. Completan su rico patrimonio arqueológico e histórico el castillo de Fatetar, la iglesia Santa María de Gracia (siglo XVI) y la antigua casa de la Cilla (siglo XVIII).

A pesar del notable interés de este patrimonio, hasta 1998 no comenzó su visión como motor para la revitalización de turismo en la localidad y su puesta en valor con este fin. En 2001 se inauguró la Exposición permanente mundo funerario íbero-romano, germen del futuro Museo Arqueológico de Espera (MAE), en la que se mostraban piezas arqueológicas tanto de los dos yacimientos principales como de los numerosos secundarios que abundan por todo el término municipal. Desde entonces permanece abierto al público convertido en un atractivo más de este pueblo que, aun contando con un gran patrimonio, es uno de los más desconocidos de toda la comarca de la Sierra de Cádiz por estar ubicado fuera de la órbita del circuito turístico más renombrado, la ruta de los Pueblos Blancos.

\section{Palabras clave}

Bornos (Cádiz) | Cádiz (Provincia) | Carissa Aurelia | Ciudades | Edad del hierro II |Época romana | Espera (Cádiz) | Esperilla | Museo Arqueológico de Espera (Cádiz) | Patrimonio arqueológico | Sierra de Cádiz | Yacimientos arqueológicos | 


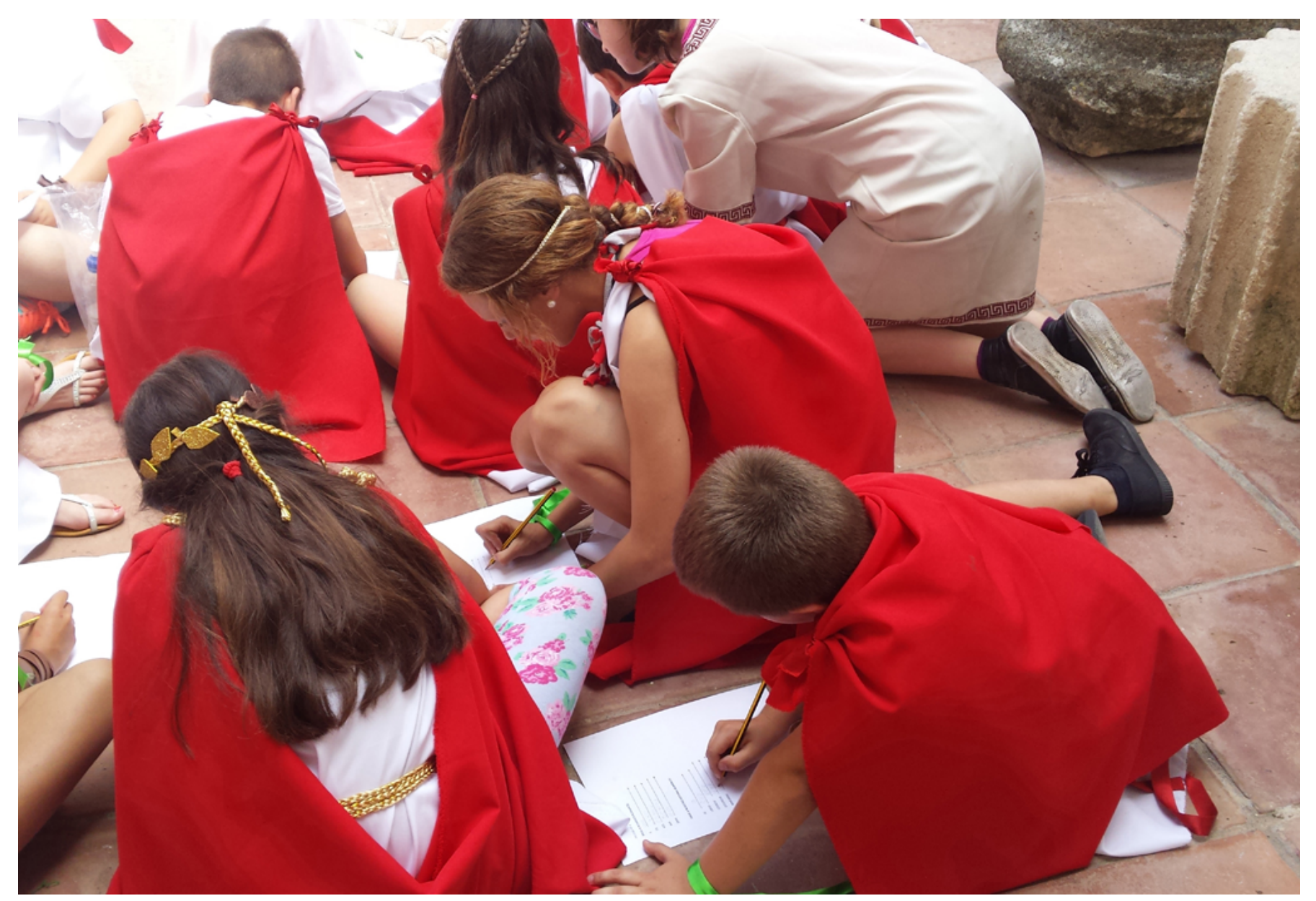

Actividades con escolares en el MAE | foto Pepa Lozano Ramírez, de todas las imágenes si no se indica lo contrario 


\section{DE EXPOSICIÓN PERMANENTE MUNDO FUNERARIO ÍBERO-ROMANO EN ESPERA A MUSEO ARQUEOLÓGICO DE ESPERA (MAE)}

Los vecinos de Espera y las distintas corporaciones municipales siempre han mostrado una gran preocupación por conservar y recuperar el rico patrimonio arqueológico del que disponían. Los yacimientos de Carissa Aurelia y Esperilla han aportado abundante material arqueológico de calidad. Los descubrimientos son consecuencia unas veces, la mayoría, por desgracia, de actuaciones clandestinas, otras veces son resultado de las escasas intervenciones de urgencia que se han realizado, o de hallazgos casuales a raíz de tareas agrícolas o escorrentías.

La creación de un museo local en el que se expusieran esos hallazgos arqueológicos era una aspiración que venía de antiguo. Sin embargo, por motivos principalmente económicos, no fue una realidad hasta 2001, cuando, con motivo del inicio del proyecto Arqueosierra II promovido por la Mancomunidad de Municipios de la Sierra de Cádiz, cuyo fin era la puesta en valor del patrimonio arqueológico de la Sierra de Cádiz, el Ayuntamiento de Espera decidió destinar los fondos necesarios para la adecuación de la planta baja del edificio de la Casa de la Cultura como lugar de exposición de las piezas arqueológicas y la colección de escultura íbero-romana allí almacenada, además de materiales que estaban en manos de particulares, los cuales habían mostrado su disposición a cederlos una vez que se contara con un espacio adecuado. La Casa de la Cultura es una casa-palacio del siglo XVIII, de propiedad municipal, en cuya planta primera se ubicaba la biblioteca pública. La planta baja, por entonces desocupada, se acondicionó para la instalación de la exposición permanente. Se unieron varias estancias separadas por tabiques y se renovaron tanto el pavimento como la instalación eléctrica. A nivel museográfico, se diseñaron la cartelería y las vitrinas, y se decidió el recorrido de la exposición. Entretanto se procedió a la recogida, recuperación y catalogación del material arqueológico. Finalmente, en julio de 2001, se inauguró oficialmente la llamada Exposición mundo funerario íbero-romano en Espera, pues la mayor parte de los materiales expuestos, incluida la colección de escultura, estaban relacionados con el tema de la muerte.

En 2003, a instancias de la Delegación Provincial de Cultura de Cádiz, se redactó un Proyecto de homologación, con el fin de que la exposición pasara a formar parte del Registro Andaluz de Museos y Colecciones Museográficas.

La Dirección General de Instituciones del Patrimonio Histórico resolvió favorablemente quedando así anotado de forma preventiva en el Registro de Museos (RESOLUCIÓN, 2004). En el período que transcurre de 2003 a 2005 se dotó a la exposición de un laboratorio y se trasladó la biblioteca municipal, quedando libre la planta primera para una futura ampliación del museo. 

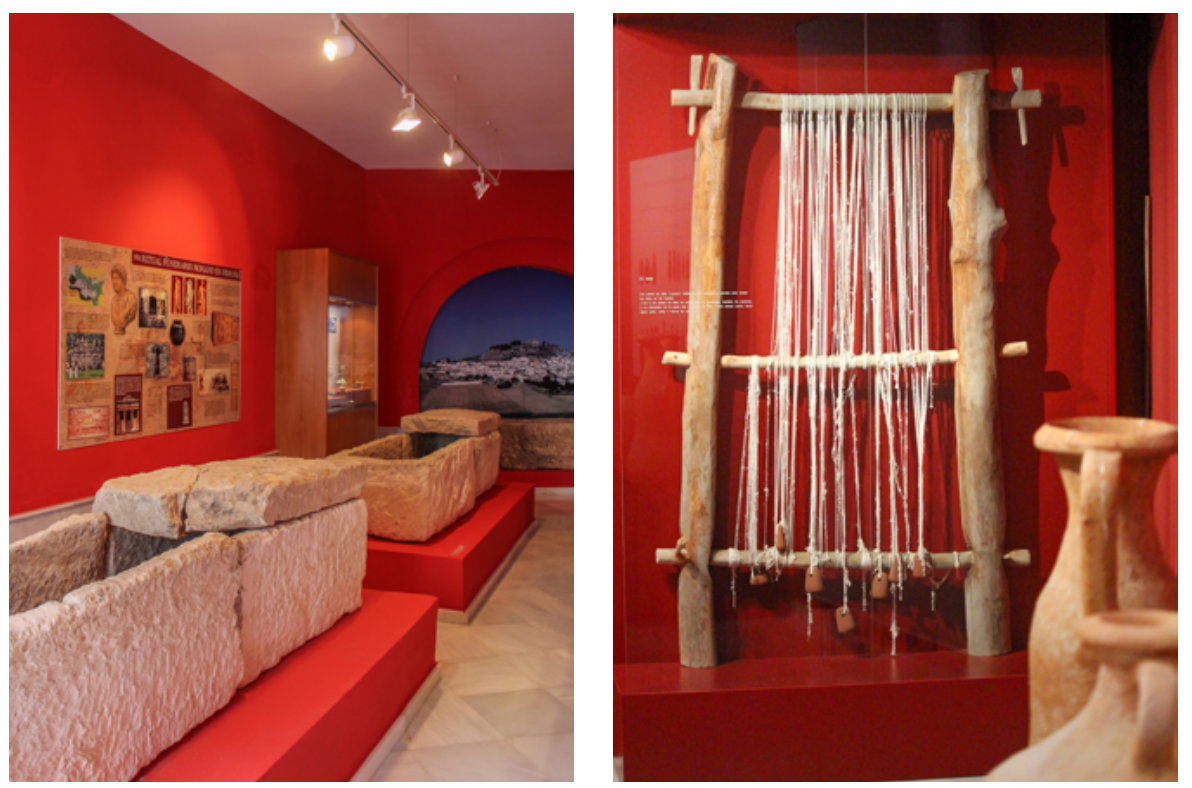

En 2006 la exposición cerró sus puertas para someterse a una importante reforma gracias al proyecto Cultur-Cad promovido por el Instituto de Empleo y Desarrollo Socioeconómico y Tecnológico de Diputación. El objetivo era adecuar el edificio entero para ser la sede definitiva del museo y la ampliación de la exposición a la planta primera. Al mismo tiempo que se ejecutaba la obra se redactó un proyecto museológico para proporcionar una estructura coherente al contenido del futuro espacio. Desde el punto de vista museográfico se diseñaron las vitrinas para las piezas, la señalética de todo el edificio y se creó el logotipo del que sería a partir de entonces denominado MAE, acrónimo de Museo Arqueológico de Espera, inaugurado el 29 de octubre de 2007.

La exposición quedó dividida temática y espacialmente ofreciendo un recorrido histórico a través de las piezas arqueológicas exhibidas.

\section{Planta baja: Prehistoria, protohistoria y mundo funerario romano. El mundo de los muertos}

En la planta baja se expone una representación de los utensilios empleados por el hombre de la sierra gaditana desde el Paleolítico-Neolítico hasta el bronce final: herramientas líticas talladas y pulimentadas, molinos de mano, utensilios de bronce, restos cerámicos, etc. El contenido más destacado de la sala es una amplia muestra de piezas pertenecientes al mundo funerario íbero-romano, entre las que destaca la importante colección de escultura zoomorfa, principalmente leones, y antropomorfa, hallada en la zona de la necrópolis de los yacimientos del término municipal de Espera. La sala está rodeada de paneles explicativos relacionados con la temática principal de la sala.

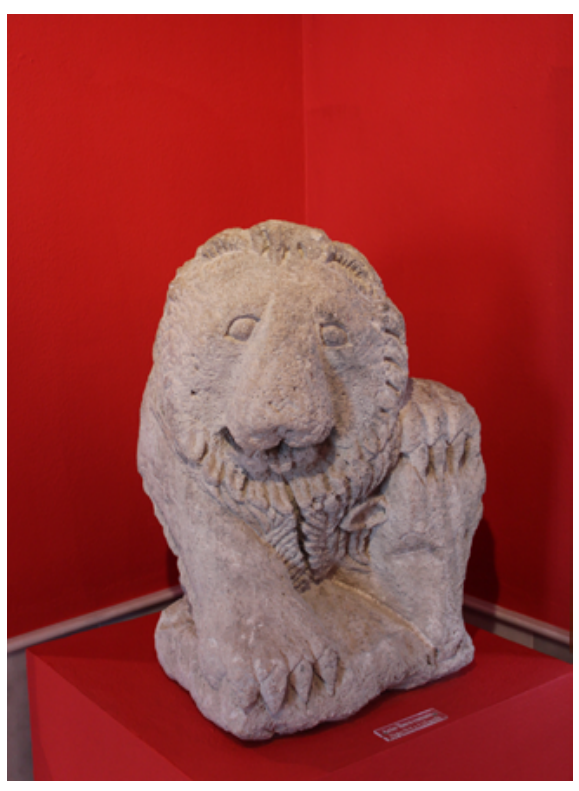

Vista general de la sala 2 de la planta baja Reproducción de telar. Planta primera León íbero-romano. Planta baja 


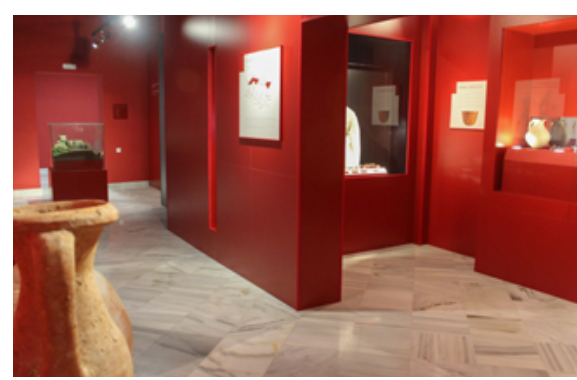

Vista general de la planta primera

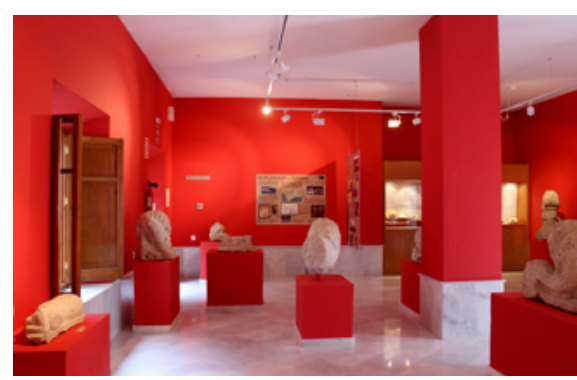

Vista general de la planta baja

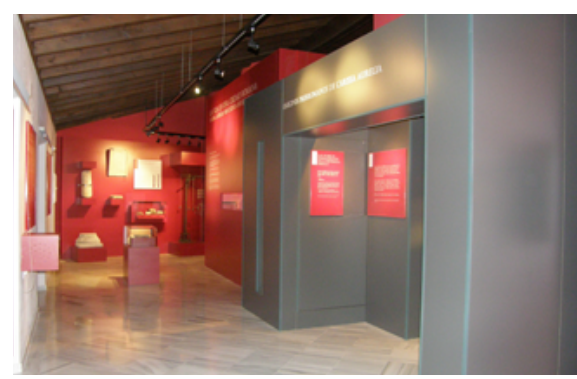

Vista general planta primera

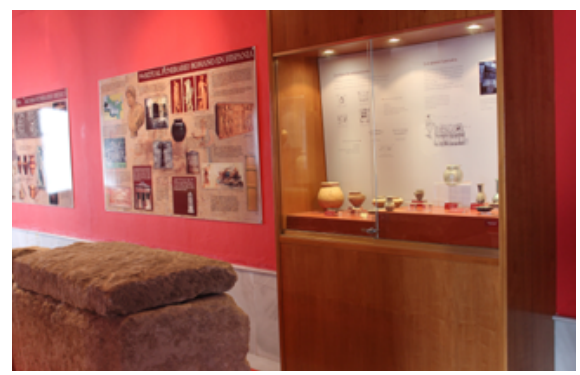

Sarcófagos tardorromanos y vitrina con ajuares funerarios. Planta baja

\section{Planta primera: La vida en la urbe y el castillo de Fatetar. El mundo de los vivos}

En contraposición al mundo funerario, en la planta primera el visitante descubrirá cómo era la vida en una ciudad romana. Tras una breve introducción sobre la etapa prerromana, la exposición nos traslada a la vida cotidiana en las urbes de Carissa Aurelia y Esperilla a través de la arquitectura, el comercio, la vestimenta de los habitantes de los yacimientos, etc. Se exponen piezas escultóricas, monedas ibéricas y romanas, elementos relacionados con la construcción (basas de columnas, fustes, tégulas, fragmentos de cornisas, de capiteles, plomadas...), pesas de telar, piedras de molino, reproducciones de ánforas, recipientes de cerámica y adornos personales como anillos, fíbulas, pinzas, espejos, etc. Continúa con la época medieval, con especial mención del castillo de Fatetar.

Se ha procurado que la exposición sea lo más didáctica posible, pues gran parte del público que acude al museo son escolares de toda la provincia. Se han redactado actividades para los distintos niveles educativos que se envían previamente a los grupos de alumnos para que acudan con una serie de conocimientos adquiridos y también se han preparado juegos que se realizan durante la visita, con el objetivo de que el aprendizaje sea ameno y divertido. Asimismo se les inculca la importancia que tiene el patrimonio arqueológico e histórico y la necesidad de cuidarlo y salvaguardarlo para las generaciones venideras.

Además de los espacios expositivos, el MAE cuenta con dependencias administrativas, laboratorio, biblioteca y una sala de audiovisuales, donde se da por finalizada la visita con la proyección de un documental sobre el patrimonio de Espera y la comarca de la Sierra de Cádiz. Este espacio es también utilizado como sala de conferencias o para la realización de diferentes actividades organizadas por el museo o por el ayuntamiento.

El próximo mes de julio se cumplirán 15 años de la inauguración de la exposición permanente. Durante todo este tiempo, a excepción de los meses en los que se realizó la segunda reforma, la exposición, luego Museo Arqueológico de Espera, ha estado abierto al público con horario fijo incluidos los fines de semana. EI MAE no solo ha cumplido con las funciones propias de un organismo de sus características: exponer, conservar, investigar y difundir el patrimonio, sino que se ha convertido en un espacio cultural de referencia en la localidad que excede las funciones propias de un museo. Es un lugar de encuentro vivo que ya forma parte de la identidad cultural de los vecinos de Espera.

EL MAE quedó definitivamente inscrito en el Registro de Museos de Andalucía por la Orden de 30 de enero de 2009 (ORDEN, 2009). 


\section{BIBLIOGRAFÍA}

- RESOlUCión de 12 de enero de 2004, de la Dirección General de Instituciones del Patrimonio Histórico, por la que se hace pública la relación de los museos anotados preventivamente en el año 2003 en el Registro de Museos de Andalucía. Boletín Oficial de la Junta de Andalucía, n. ${ }^{\circ}$ 36 , de 23 de febrero de 2004

- ORDEN de 30 de enero de 2009, por la que se autoriza la creación del Museo Arqueológico Municipal de Espera, en Espera (Cádiz), y se ordena su inscripción en el Registro de Museos de Andalucía. Boletín Oficial de la Junta de Andalucía, n. ${ }^{\circ}$ 51, de 16 de marzo de 2009

- LEY 8/2007 de 5 de octubre de Museos y Colecciones Museográficas de Andalucía. Boletín Oficial de la Junta de Andalucía, n. ${ }^{\circ} 205$, de 18 de octubre de 2007

- BARRAgÁN JANÉ, M. (2001) Sistema Andaluz de Museos y registro de Museos de Andalucía. PH: Boletín del instituto Andaluz del Patrimonio Histórico, n. ${ }^{\circ} 34$, marzo, 2001, pp. 159-165 


\section{Información de bienes culturales. Sierra de Cádiz}

La Guía Digital del Patrimonio Cultural de Andalucía, desarrollada por el IAPH (http://www.iaph.es/web/canales/ conoce-el-patrimonio/guia-digital/), nos ofrece, de forma integrada, toda la información patrimonial de los municipios andaluces.

Sobre la demarcación de la Sierra de Cádiz, que comprende los municipios de Alcalá del Valle, Algar, Algodonales, Arcos de la Frontera, Benaocaz, Bornos, El Bosque, El Gastor, Espera, Grazalema, Olvera, Prado del Rey, Puerto Serrano, Setenil de las Bodegas, Torre Alháquime, Ubrique, Villaluenga del Rosario, Villamartín y Zahara de la Sierra, en la Guía podemos encontrar información sobre un total de 801 inmuebles y 1462 objetos muebles, información también disponible en las bases de datos del Patrimonio Inmueble de Andalucía (http://www.iaph.es/patrimonio-inmueble-andalucia/) y del Patrimonio Mueble de Andalucía (http://www.iaph.es/ patrimonio-mueble-andalucia/), respectivamente.

Instituto Andaluz del Patrimonio Histórico, Centro de Documentación y Estudios

URL de la contribución <www.iaph.es/revistaph/index.php/revistaph/article/view/3762>

\section{Patrimonio inmueble}

De los 801 registros de inmuebles de esta demarcación recogidos por la Guía Digital, el $56 \%$ corresponde al patrimonio arqueológico; el 29\% , al patrimonio etnológico y el $15 \%$, al patrimonio arquitectónico.

El poblamiento en la zona se establece desde la Prehistoria Reciente con la presencia de lugares con pinturas rupestre, como el grupo de la peña de Algodonales y la Cueva VR15, en Villaluenga. Se encuentran construcciones megalíticas, como el dolmen del Gigante en El Gastor, El Toconal I en Olvera o la sepultura de la Giganta en Villaluenga, y ya de una forma más estable existen poblados desde el Bronce Final hasta la Época romana, pasando por la época ibérica con ciudades como Iptuci.

Las fortificaciones han dado lugar a núcleos de población singulares y derivan de su condición fronteriza en la Edad Media. Entre las principales están el castillo de Aznalmara (Benaocaz), el poblado fortificado de Peñaloja (Grazalema), el castillo de Setenil de las Bodegas, el de Torre-Alháquime, el castillo de Fátima (Ubrique), o el de Zahara de la Sierra.

En cuanto al patrimonio urbano, los centros históricos de Algodonales, Arcos de la Frontera, Benaocaz, Bornos, Grazalema, Olvera, Setenil de las Bodegas, Torre Alháquime, Ubrique y Zahara de la Sierra están inscritos en Catálogo General del Patrimonio Histórico Andaluz como conjuntos históricos.

De la Edad Moderna se contabilizan algunas construcciones religiosas como las iglesias de Santa María de la Asunción, de San Francisco y de San Pedro en Arcos de la Frontera; en Espera, la iglesia de Nuestra Señora de Gracia; la de Nuestra Señora de la Aurora en Grazalema; la de San Miguel en Villaluenga del Rosario; o la iglesia de Santa María de la Mesa en Zahara de la Sierra.
Por su parte, de la edad contemporánea se han documentado 27 inmuebles del siglo XX incluidos en el Registro Andaluz de Arquitectura Contemporánea (RAAC).

Pertenecientes al patrimonio etnológico, están registradas numerosas viviendas, molinos harineros, almazaras, lavaderos, hornos, etc. Las salinas de interior se encuentran representadas en las salinas de Hortales en El Bosque, las salinas Ventas Nuevas en El Gastor, la salina Salinillas en Prado del Rey y entre las salinas de sierra se encuentra la salinas de Raimundo en Prado del Rey. También han sido documentados cortijos pertenecientes al Inventario de Cortijos, Haciendas y Lagares llevado a cabo por el Servicio de Arquitectura de la Consejería de Obras Públicas, desde 1992.

Las principales fuentes de información sobre este patrimonio de la Sierra de Cádiz son el Catálogo de Yacimientos Arqueológicos con Pinturas Rupestres, el 
Inventario de Yacimientos Arqueológicos deAndalucía, el Inventario de Arquitectura Popular, el Inventario de Cementerios de Andalucía, el Inventario de Cortijos, Haciendas y Lagares, el Inventario de Arquitectura Popular, el Registro Andaluz de Arquitectura Contemporánea y el Boletín Oficial de la Junta de Andalucía para los bienes protegidos.

\section{Patrimonio Mueble}

La Guía Digital del Patrimonio Cultural también ofrece información referida a 1462 objetos muebles de carácter artístico de la Sierra de Cádiz, distribuidos en tres municipios y pertenecientes al Inventario de Bienes Muebles de la Iglesia Católica. En Arcos de la Frontera hay 1.197 objetos muebles documentados; de estos, 667 pertenecen a la Iglesia de Santa María de la Asunción; 525 se encuentran en la Iglesia de San Pedro; y 5 bienes pertenecen al Hospital de San Juan de Dios. En el municipio de Espera se contabilizan 139 objetos muebles pertenecientes a la Iglesia de Nuestra Señora de Gracia y en Zahara de la Sierra hay 126 bienes en la Iglesia de Santa María de la Mesa. Se puede consultar en la base de datos del Patrimonio Mueble de Andalucía: http://www.iaph. es/patrimonio-mueble-andalucia/

\section{Bibliografía}

En la Guía Digital también encontramos 370 referencias bibliográficas sobre la demarcación de la Sierra de Cádiz. El municipio que posee mayor cantidad de referencias es Arcos de la Frontera (84), seguido de Bornos (37), Olvera (32) y Espera (29).

\section{Cartografía}

Se encuentran georreferenciados 577 inmuebles (ver mapa): arqueológicos, el 52\%; etnológicos, el 34\%; y arquitectónicos, el 14\%. Algunos de ellos pueden consultarse a través del Localizador Cartográfico del patrimonio Cultural: http://www.iaph.es/localizador-cartografico-patrimonio-cultural-andalucia/

\section{Patrimonio Inmaterial}

En el Atlas del Patrimonio Inmaterial de Andalucía, actualmente documentadas, hay 57 actividades de interés etnológico, distribuidas según temática:

$>$ Rituales festivos: 32 registros

$>$ Oficios y Saberes: 12 registros

> Modos de expresión: 10 registros

$>$ Alimentación y sistemas culinarios: 3 registros

Información disponible en: http://www iaph.es/patrimonio-inmaterial-andalucia/

\section{Repositorio de Activos Digitales}

En el Repositorio de Activos Digitales (http://repositorio.iaph.es/) se contabiliza el siguiente número de imágenes:

$>1569$ de inmuebles

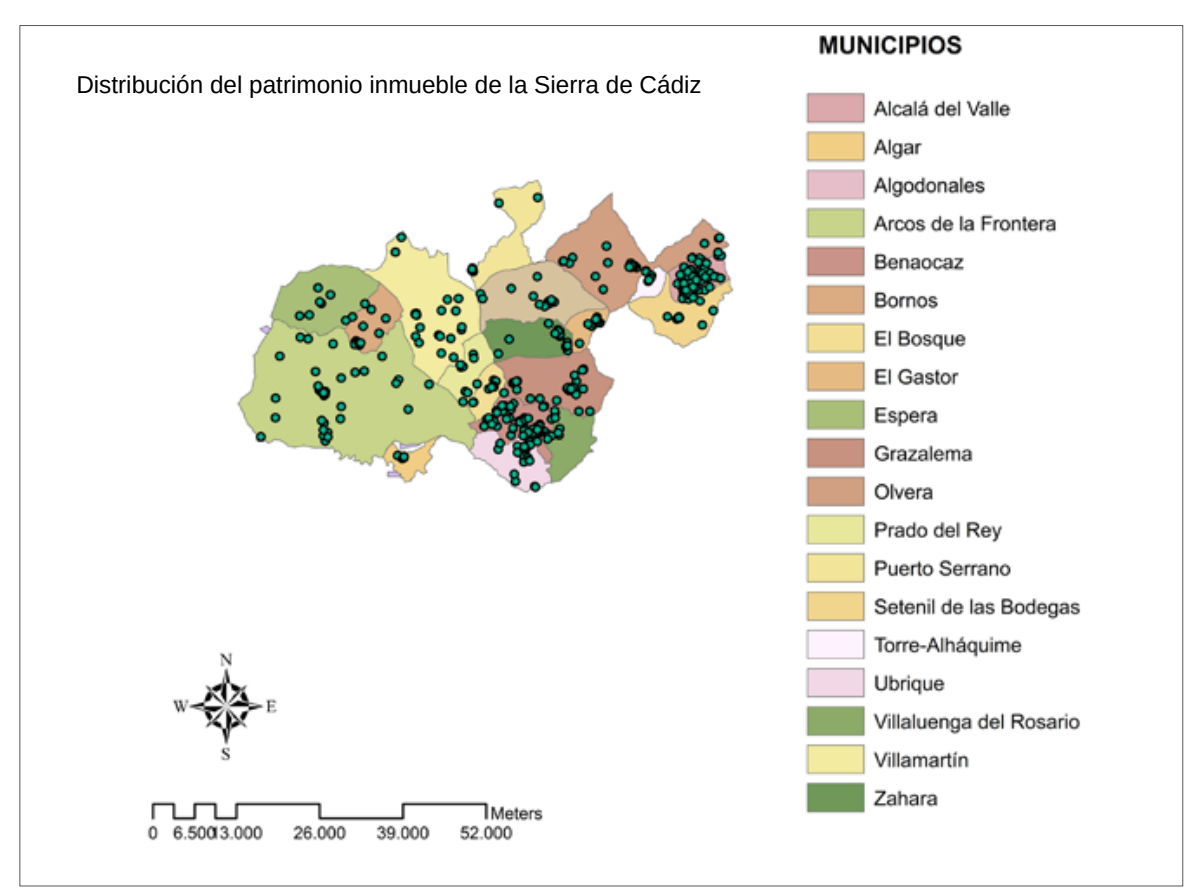

$>2673$ de bienes muebles

$>178$ de patrimonio inmaterial

\section{Rutas Culturales}

En la Guía Digital encontramos una ruta cultural que tiene como uno de sus hitos el municipio de Grazalema: Construyendo y blanqueando. Caminos de cal en Andalucía y Marruecos.

Esta ruta pasa por la Sierra de Cádiz, un espacio en el que nos encontramos con los "pueblos blancos", una denominación que hace referencia al color de las paredes y al uso de la cal como elemento destinado a la ornamentación. En esta comarca serrana, una de las localidades re-lacionadas con la producción calera es Grazalema. Además de los usos conocidos de blanqueo y construcción, la cal en Grazalema se utilizaba para labores de agricultura y ganadería. ver http://www.iaph.es/web/canales/ conoce-el-patrimonio/rutas-culturales/ 